Article

\title{
Fatty Acid Changes in Nearshore Phytoplankton under Anthropogenic Impact as a Biodiversity Risk Factor for the World's Deepest Lake Baikal
}

\author{
Alyona Alexandrovna Nikonova ${ }^{1, *}$, Sergey Mikhailovich Shishlyannikov ${ }^{1,2} \mathbb{D}$, Nadezhda Antonovna Volokitina ${ }^{1}$, \\ Yuri Pavlovich Galachyants ${ }^{1}$, Yuri Sergeevich Bukin ${ }^{1}$ (D), Vadim Vasil'evich Blinov ${ }^{1}$ (D), \\ Ruslan Yur'evich Gnatovsky ${ }^{1}$ and Svetlana Semyonovna Vorobyeva ${ }^{1}$ \\ 1 Limnological Institute of the Siberian Branch of the Russian Academy of Sciences, 3, Ulan-Batorskaya Street, \\ 664033 Irkutsk, Russia; sershilin@gmail.com (S.M.S.); nshelest@mail.ru (N.A.V.); yuragal@gmail.com (Y.P.G.); \\ bukinyura@mail.ru (Y.S.B.); bwad@lin.irk.ru (V.V.B.); gnat@lin.irk.ru (R.Y.G.); lana@lin.irk.ru (S.S.V.) \\ 2 Smorodintsev Research Institute of Influenza, 15/17, Prof. Popov Street, 197376 Saint Petersburg, Russia \\ * Correspondence: alenaxis@list.ru
}

check for updates

Citation: Nikonova, A.A.; Shishlyannikov, S.M.; Volokitina, N.A.; Galachyants, Y.P.; Bukin, Y.S.; Blinov, V.V.; Gnatovsky, R.Y.; Vorobyeva, S.S. Fatty Acid Changes in Nearshore Phytoplankton under Anthropogenic Impact as a Biodiversity Risk Factor for the World's Deepest Lake Baikal. Diversity 2022, 14, 55. https:// doi.org/10.3390/d14010055

Academic Editors: Eduardo Antonio Morales and Alan Christian

Received: 24 October 2021

Accepted: 3 January 2022

Published: 14 January 2022

Publisher's Note: MDPI stays neutral with regard to jurisdictional claims in published maps and institutional affiliations.

Copyright: (C) 2022 by the authors. Licensee MDPI, Basel, Switzerland. This article is an open access article distributed under the terms and conditions of the Creative Commons Attribution (CC BY) license (https:// creativecommons.org/licenses/by/ $4.0 /)$
Abstract: In this study, we present results on fatty acid analysis of phytoplankton of Lake Baikal, the world's deepest lake, which differs from other lakes by its oceanic features. Since we used a large-mesh net, the net sample phytoplankton were primarily represented by the large elongated diatom Synedra acus. subsp. radians (Kützing) Skabichevskij. The similar algae composition of net samples of spring season phytoplankton collected at different sites of the lake allows us to compare results of the fatty acid analysis of these samples. The phytoplankton diversity of the sedimentation samples was contrary represented by 32 algae species. There are clear changes in the fatty acid composition of net phytoplankton exposed to anthropogenic impacts of varying intensity. The content of polyunsaturated fatty acids in phytoplankton collected from central stations (pelagic stations at a distance of $\sim 10-30 \mathrm{~km}$ from the shoreline) without anthropogenic impact was higher by up to $15 \%$ than phytoplankton collected from nearshore stations (littoral stations at a distance of $\sim 0.01-0.05 \mathrm{~km}$ from the shoreline) and offshore stations (pelagic stations at a distance of $\sim 3 \mathrm{~km}$ from the shoreline). The interlaboratory precision of fatty acid determination of phytoplankton is estimated as $\leq 10 \%$. We found high content of the lipid peroxidation marker $\left(80-340 \mu \mathrm{g} \mathrm{g}^{-1}\right.$ of dry weight) in phytoplankton from nearshore and offshore stations with intensive anthropogenic impact. In phytoplankton from central stations, we did not find any lipid peroxidation. Determination of unsaturated fatty acids, coupled with analysis of fatty acid peroxidation products, can be used to evaluate the level of anthropogenic impact in terms of ecological health and biodiversity conservation.

Keywords: Lake Baikal phytoplankton; Synedra acus; fatty acids; peroxidation; nearshore; pelagic; PUFA; anionic surfactants; oxidative stress; linear alkylbenzene sulphonates

\section{Introduction}

Lake Baikal is the world's deepest (maximum depth of $1642 \mathrm{~m}$ ) [1,2] and oldest (20-25 million years) lake, containing $23,615.39 \mathrm{~km}^{3}$ of fresh water with a mineralization of $96-98 \mathrm{mg} \mathrm{L}^{-1}$. Lake Baikal, a rift lake, is located in the southern part of Eastern Siberia (Russia) and comprises three basins: northern, central, and southern [3,4].

There are both littoral and pelagic zones in Lake Baikal $[3,5,6]$. The lake is $636 \mathrm{~km}$ long, with a maximum width of $79 \mathrm{~km}$. Its littoral zone reaches $80-120 \mathrm{~m}$ of depth, including the nearshore zone, which extends to a $25 \mathrm{~m}$ depth [7,8]. The tectonic terrace on the western flank rises over the lake surface at heights of about 300-1500 m and continues steeply underwater to 1200-1400 m. It then turns into the valley bottom, which slants toward the east coast [9]. As demonstrated in a schematic bathymetric map (Figure 1), the platform is fairly shallow near the shore but drops off steeply, especially on the western flank. This 
platform step forms a boundary between the littoral and pelagic zones. The surface area of

Lake Baikal is $32,822 \mathrm{~km}^{2}$, of which the littoral zone occupies only $\sim 3.4 \%$.

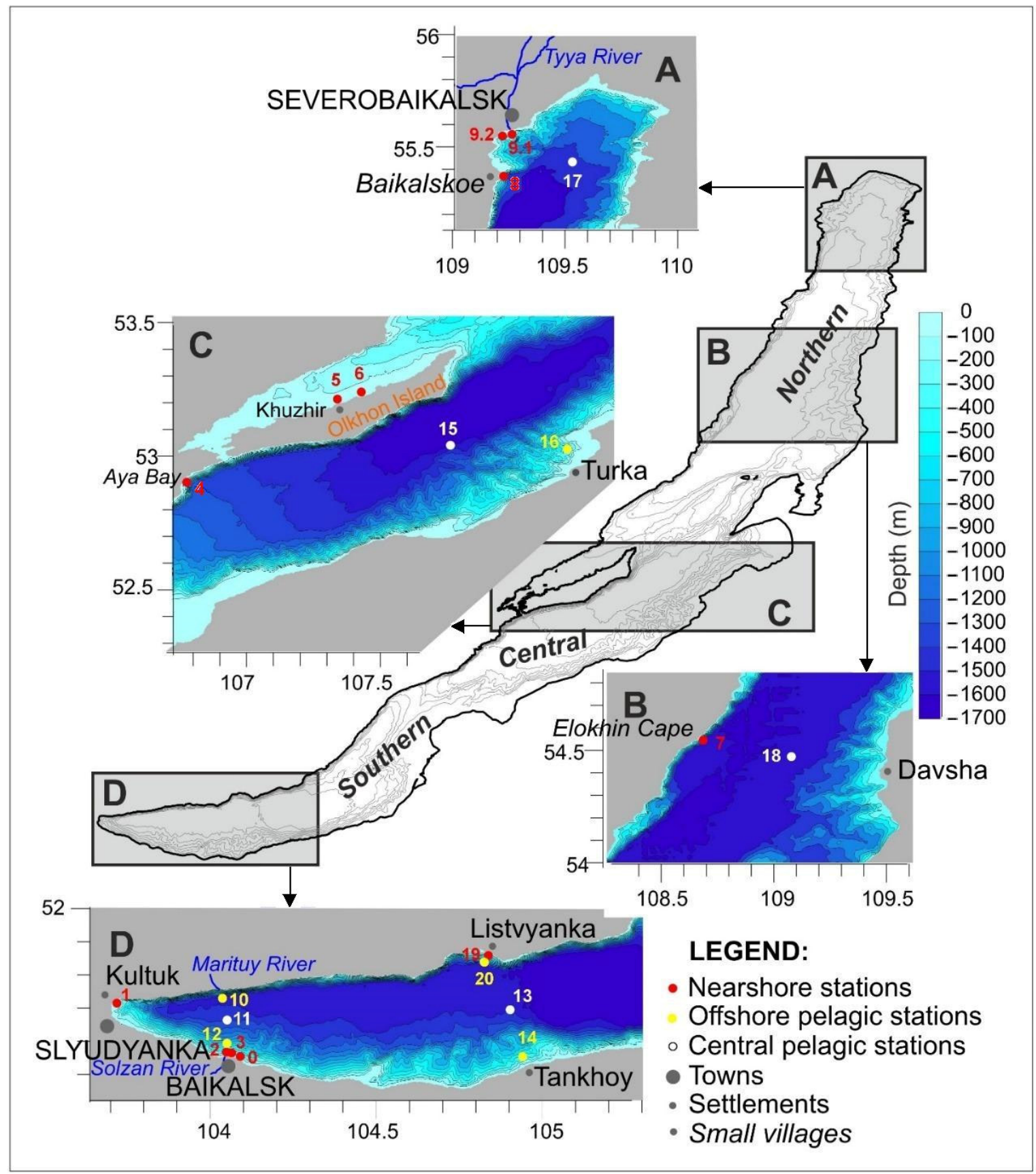

Figure 1. Bathymetric map of Lake Baikal. Sampling sites are marked.

Nevertheless, the nearshore zone of Lake Baikal is the most productive, containing more than $98 \%$ of all bottom dwellers, such as Porifera, Polychaeta, Oligochaeta, and other worms, along with Sagina, Isopoda, Trichoptera, Chironomidae, Mollusca, and fishes. Their biomass in the southern basin was $620 \mathrm{~kg}$ per hectare at depths of $\leq 4 \mathrm{~m}$ and 100-150 kg per hectare at depths of 20-70 $\mathrm{m} \mathrm{[10,11].}$

Phytoplankton are the primary producers of organic matter in Lake Baikal, inhabiting the photic zone at depths of $\sim 60-120 \mathrm{~m}$. Intensive photosynthesis takes place in this zone. Phytoplankton also inhabit the epipelagic zone, a zone with depths of $\sim 200-300 \mathrm{~m}$ and maximum vertical mixing of water [10]. Microalgae live in the deep-water pelagic zone 
down to $750 \mathrm{~m}$ of depth [12] without cell division due to mixotrophic growth [13] and the rest stage of growth during adverse conditions [14]. Some microalgae and their spores drop to the bottom water layer during the disadvantageous season, floating to the surface later in the spring period. After blooming, phytoplankton become food for protozoa, zooplankton, benthic organisms, and bacteria, helping maintain biodiversity. Spring primary production of Lake Baikal phytoplankton reaches $\sim 160$ tons per hectare (i.e., $\sim 80 \%$ of the annual biomass) [10]. Phytoplankton are highly sensitive to environmental changes, and their health benefits the well-being of the entire lake ecosystem [15-18].

The high productivity and biodiversity in the nearshore zone of Lake Baikal are due to unique oceanic or marine features of climate, hydrological regime, and bathymetry. In oceans (and seas), there are places where the ocean floor deepens closer to shore. In coastal areas of oceans, the interaction of winds and currents generates vertical movement of cold, nutrient-rich deepwater towards the surface (upwelling). As in oceans, upwelling is a typical phenomenon for Lake Baikal $[19,20]$. Causes of vertical water movement include asymmetric depression and the presence of high-pressure thermal and cold-water springs through bottom cracks. Another cause is climate features and winds formed due to the great length of Lake Baikal from south to north, which leads to a baric gradient between the northern and southern basins. Winds also cause movement in the water column down to the bottom [21,22]. The most intensive upwelling processes and nutrient enrichment take place near the western and northern coasts of Lake Baikal [21-24]. These several peculiarities coupled with the runoff of ten largest tributaries of the lake (the total water discharge of $\sim 1522 \mathrm{~m}^{3} \mathrm{~s}^{-1}$ ) lead to an almost unlimited concentration of nutrients in the coastal zone, which is sufficient for the autotrophic organisms providing the bioproductivity of the lake [24-26].

For Baikal phytoplankton, the bulk of primary production comprises lipids [27]. The fatty acid (FA) composition of phytoplankton depends on metabolism, abiotic factors [28-30], and biotic factors. Lake Baikal phytoplankton produce esterified and free fatty acids [29], including essential polyunsaturated fatty acids (PUFA) [31,32]. FAs migrate through food webs and have an impact on the functioning and energetic potential of all organisms $[33,34]$. Changes in phytoplankton FA composition can elucidate the ecosystem stress caused by anthropogenic impact [35-37].

For live cells, which are the structural units of whole organisms, the cell wall is the first target of negative anthropogenic impacts. Phospholipids are dominant constituents of the cell wall. There are two known routes for lipid destruction in the cell. The first is the $\alpha-, \beta-$, and $\omega$-oxidation of lipids by enzymes with the formation of numerous vital compounds, including acetyl coenzyme A (acetyl-CoA) with its further oxidation to adenosine triphosphate (ATP) and energy generation. The second is lipid peroxidation. One final product of peroxidation is malondialdehyde (MDA), which can exist in the cell in free (f-MDA) and covalently-bonded (b-MDA) forms [38-40]. MDA reacts with lipids, thiol groups, and amino groups of nucleic acids of proteins, as well as with lipoproteins and DNA, resulting in the destruction of these biological molecules [34-36]. MDA can also react with DNA to form mutagenic adducts [41,42]. Lipid peroxidation products, including MDA, can be analyzed in their reaction with thiobarbituric acid, at which point they are called thiobarbituric reactive substances (TBARS).

In large aquatic ecosystems, the nearshore zone is much more exposed to negative anthropogenic impact than the pelagic zone [15] and can result in stress. The narrow nearshore zone of Lake Baikal, with its unique biodiversity, warrants concern. Changes in littoral phytoplankton from 2000 to 2015 were observed [43]. For example, the biomass of atypical small unicellular green algae and atypical filamentous green algae increased significantly. On the other hand, psychrophilic pelagic phytoplankton did not change significantly from 1964 to 2011. Diatoms comprised about 50-90\% of biomass [44], and changes in the structure of benthic communities [45] and the death of Lake Baikal sponges in the littoral zone were also observed [46,47]. 
Understanding the dynamics and functioning of nearshore communities is necessary to decrease the anthropogenic impact on the littoral zone. This study aims to reveal stress in Baikal phytoplankton through the analysis of FAs and their peroxidation products as a response of the environment to anthropogenic impacts of different intensities.

\section{Experiment}

\subsection{Sample Collection}

For Lake Baikal, a delay of seasonal onsets in the coastal zone is common compared to the nearby continental zone [24]. Phytoplankton samples were collected in the spring seasons of 2014, 2016, 2018, and 2020, from 28 May to 20 June, using the vertical Juday-type net with $100 \mu \mathrm{m}$ mesh size. Samples were collected from a depth of $20 \mathrm{~m}$ at the coastal and pelagic stations located in the three Lake Baikal basins (Figure 1).

All samples were collected from the stations of three types. These types differ by their distances from shore. The differences are the following.

1. Pelagic phytoplankton were collected from central stations located within the central deep-water areas of the three basins. Of all stations, these were the farthest from shore. The distance from the shoreline was $\sim 10-30 \mathrm{~km}$. The central stations no. 11, 13, 15, 17, and 18 were considered to lack anthropogenic impact.

2. Pelagic phytoplankton were collected from offshore pelagic stations located $\sim 3 \mathrm{~km}$ from the shoreline. The offshore stations no. 10,12,14, and 16 were considered to have a low anthropogenic impact.

3. Coastal phytoplankton were collected from the stations located about $0.01-0.05 \mathrm{~km}$ from the shoreline. These are considered nearshore stations. Some were located near cities (no. 0, 2, 3, and 9) and settlements (no. 1, 5, and 8). The nearshore stations no. 4, 5, and 6 were located in areas with intensive recreation. Nearshore stations no. 4 and 7 were located far from any settlements.

For the spring season, the phytoplankton Bacillariophyta and Dinophyta microalgae are typical. For example, the mean cell length of the dominant Synedra acus subsp. radians (Kützing) Skabichevskij (this name is currently regarded as a synonym of Fragilaria radians (Kützing) D.M. Williams and Round) reaches 142-288 $\mu \mathrm{m}$, and the length of some cells reaches $500 \mu \mathrm{m}$. These algae dominated from 2014 to 2020. Aulacoseira baikalensis (Wislouch) Simonsen, a diatom endemic to Lake Baikal, forms filaments up to 160-1000 $\mu \mathrm{m}$ long, but this species was not dominant from 2014 to 2020. We used a $100 \mu \mathrm{m}$ mesh net to obtain $S$. acus as net samples, excluding other small algae because different algae species have various responses to stress factors. This allows us to compare the results of chemical analysis of phytoplankton samples obtained in different parts of the lake. Samples containing zooplankton organisms were filtered through a nylon net with 400 mesh size to separate them from phytoplankton. Phytoplankton net samples were immediately filtered onto glass fiber filters ( $47 \mathrm{~mm})$, wrapped in aluminum foil, and stored at $-20{ }^{\circ} \mathrm{C}$ before chemical analysis.

The separate samples of phytoplankton were collected to analyze Baikal phytoplankton diversity by the classical sedimentation method [6]. Water from the surface down to a depth of $1 \mathrm{~m}$ was sampled using the bathometer. A water sample of $1 \mathrm{~L}$ volume was poured into a plastic bottle, which was kept in dark at $20{ }^{\circ} \mathrm{C}$. For the estimation of algal biomass, samples were fixed with Lugol's solution. The sedimentation process lasted 10 days. Supernatant was removed by drop method using a siphon. It was shown previously that there were no algae cells in each drop of the removed supernatant. Samples then underwent concentration to $0.5-1 \mathrm{~mL}$. Cells in concentrated sedimentation samples were subsequently identified and counted using light microscopy (Axiovert 200, Carl Zeiss, Jena, Germany) at $400 \times$ magnification. According to microscopic analysis, zooplankton content was negligible in all net samples $(<0.5 \%)$. The number of cells was converted into phytoplankton biomass, taking into account the biovolume measurements of individual cells. Mean cell dimensions were used to estimate cell biovolumes for different species. 
The separate water samples were collected at coastal $(n=53)$ and pelagic $(n=4)$ sites in the three basins to analyze anionic surfactant concentrations. Surface water to a depth of $1 \mathrm{~m}$ was sampled in autumn 2019, from 13 to 22 September, and in the spring season 2020, from 28 May to 10 June, using the bathometer.

\subsection{Lipid Extraction and Derivatization of FA to Fatty Acid Methyl Esters (FAMEs)}

Wet sample weights ranged from $0.15-0.20 \mathrm{~g}$. The humidity of the samples was estimated gravimetrically, with values reaching $\sim 90 \%$. To extract lipids from replicate samples, $1.2 \mathrm{~mL}$ of Folch solution (chloroform-methanol, 2:1, by volume) was added to each sample. Samples then underwent extraction for 5 min using a $50 \mathrm{~Hz}$ ultrasonic bath, after which $0.35 \mathrm{~mL}$ of distilled water was added to the extracts. The mixtures were vigorously shaken for $0.5 \mathrm{~min}$ and centrifuged at 13,000 rpm for $3 \mathrm{~min}$. The chloroform extracts were put into $10 \mathrm{~mL}$ glass vials and the solvent evaporated using an argon stream [31].

Fatty acid methyl esters (FAME) were derived through the acidic esterification of fatty acids. First, $4.5 \mathrm{~mL}$ of $2 \% \mathrm{H}_{2} \mathrm{SO}_{4}$ solution in methanol was added to the dry fraction. The bottles were covered with aluminum foil caps and kept for $1.5 \mathrm{~h}$ at $55^{\circ} \mathrm{C}$. Next, $0.8 \mathrm{~mL}$ of $n$-hexane was added to the FAME solutions and the samples were cooled to room temperature. FAMEs were extracted twice with $n$-hexane $(3 \mathrm{~mL} \times 2 \mathrm{~min})$. The extracts were first dried with anhydrous $\mathrm{Na}_{2} \mathrm{SO}_{4}$ and then concentrated to $1 \mathrm{~mL}$ volume using argon stream. An internal standard was added to the extract.

\subsection{FAME Analysis by Gas Chromatography with Flame-Ionization (GC-FID) and Mass-Spectrometric Detection (GC-MS)}

For qualitative and quantitative analyses, the internal standard $\left(1 \mathrm{mg} \mathrm{mL}^{-1}\right.$ of dodecyl ether solution in n-hexane) and external standard solutions of FAs "FAME Mix C4-C24" and "methyl cis-4,7,10,13,16,19-docosahexaenoic acid" solution (both Supelco, USA) were used. Qualitative analysis of FAMEs by GC-MS was carried out using the Agilent 6890B GC System coupled to the 7000C GC/MS Triple Quad mass spectrometer (Agilent, USA). The injector temperature was $290^{\circ} \mathrm{C}$; the injection volume was $2 \mu \mathrm{L}$ in splitless mode; the quadrupole temperature was $150{ }^{\circ} \mathrm{C}$; the ion source temperature was $230{ }^{\circ} \mathrm{C}$; the ionization energy was $70 \mathrm{eV}$. Chromatographic peaks were detected in the $m / z$ 40-500 range. FAMEs were identified based on retention times and their mass spectra using the NIST Mass Spectral Search Program for the NIST/EPA/NIH Mass Spectral Library software (V. 2.2).

Quantitative analysis of FAMEs was carried out using a Shimadzu GC-2010-Plus gas chromatograph (Shimadzu, Japan). Injection of $2 \mu \mathrm{L}$ of sample into the column was carried out in the splitless regime using an Optima-17MS GC column (30 m $\times 0.25 \mathrm{~mm}$, SGE Macherey-Nagel, Germany). The injector temperature was $310^{\circ} \mathrm{C}$; the injection volume was $2 \mu \mathrm{L}$ in splitless mode; the detector temperature was $310^{\circ} \mathrm{C}$; the hydrogen velocity was $40 \mathrm{~mL} / \mathrm{min}$; the air velocity was $400 \mathrm{~mL} / \mathrm{min}$; the carrier-gas velocity (helium) was $30 \mathrm{~mL} / \mathrm{min}$; the linear velocity was $28.5 \mathrm{~cm} / \mathrm{s}$. Chromatography was carried out by heating the column first from $80{ }^{\circ} \mathrm{C}$ to $120^{\circ} \mathrm{C}$ at the rate of $10{ }^{\circ} \mathrm{C} / \mathrm{min}$ and then to $260{ }^{\circ} \mathrm{C}$ at the rate of $2.5^{\circ} \mathrm{C} / \mathrm{min}$.

\subsection{Fatty Acid Peroxidation Estimate by Spectrophotometric Determination of Thiobarbituric acid} Reactive Substances (TBARS)

Thiobarbituric acid reactive substances (TBARS) can form pink TBA 2 -TBARS adducts with thiobarbituric acid (TBA) with an absorption maximum at $532 \mathrm{~nm}$, which is a true indicator of lipid peroxidation $[38,48,49]$. In our study, we analyzed TBARS using the modified technique. Wet sample weights ranged from $0.15-0.20 \mathrm{~g}$ at $\sim 85-90 \%$ humidity. Samples were placed in plastic, 2-mL Eppendorf taste-tubes, and $1 \mathrm{~mL}$ of $10 \%$ trichloroacetic acid (TCA) solution was added. Samples were sonicated for $5 \mathrm{~min}$ in a $50 \mathrm{~Hz}$ ultrasonic bath and centrifuged at 13,000 rpm for $3 \mathrm{~min}$. The supernatant was put into $5 \mathrm{~mL}$ glass vials with plastic screw caps and mixed with $2 \mathrm{~mL}$ of $0.5 \%$ TBA solution in $10 \%$ TCA. The mixture was kept for $0.5 \mathrm{~h}$ at $95^{\circ} \mathrm{C}$, cooled, and centrifuged. Absorbance was measured using a Cintra-20 spectrophotometer (GBC, Australia) and standart quartz quvettes (path 
length $1 \mathrm{~cm}$ ). The TBARS extinction coefficient was $155 \mathrm{mM}^{-1} \mathrm{~L}$. Baseline absorption was measured at $532 \mathrm{~nm}$ using the solution obtained by mixing $1 \mathrm{~mL}$ of $10 \%$ TCA and $2 \mathrm{~mL}$ of $0.5 \%$ TBA solutions. The TBARS absorption was measured at $532 \mathrm{~nm}$. The limit of quantification (LOQ) of $1.21 \mu \mathrm{mol} \mathrm{mL}^{-1}$ extract and the limit of determination (LOD) of $0.51 \mu \mathrm{mol} \mathrm{mL}{ }^{-1}$ via spectrophotometry were determined by Rakita et al. [50].

\subsection{Statistical Data}

The laboratory precision of FAME determinations was estimated by calculating the relative standard deviations (RSD) of two replicate results from the average value using the degree of freedom number $f=22$. For selected subgroups, the homogeneity of variations was checked using Fisher and Cochran tests [51]. The repeatability of the technique for total FAME content was characterized by $V=6 \%$. We also used three replicates for the in vitro microalgae growing experiment.

For the determination of similarities and differences between natural samples and laboratory cultures in terms of FA concentrations and profiles, the principal component analysis of multidimensional statistics was used [52]. Results were visualized using the Statistica software.

To determine similarities between the fatty acid spectra of samples, cluster analysis was carried out using the Statistica software. To estimate distances between stations, Ward's method based on multifactorial variance analysis was used. The matrix of distances was calculated using the Euclidean method.

\subsection{Cultivation of the S. acus}

S. acus diatoms were grown in $100 \mathrm{~cm}^{3}$ Erlenmeyer flasks at $+6{ }^{\circ} \mathrm{C}$ for 50 days with the chemically defined medium (DM medium) containing $\mathrm{Ca}\left(\mathrm{NO}_{3}\right)_{2} \times 4 \mathrm{H}_{2} \mathrm{O}\left(20 \mathrm{mg} \mathrm{L}^{-1}\right)$, $\mathrm{KH}_{2} \mathrm{PO}_{4}\left(12.4 \mathrm{mg} \mathrm{L}^{-1}\right), \mathrm{MgSO}_{4} \times 7 \mathrm{H}_{2} \mathrm{O}\left(25 \mathrm{mg} \mathrm{L}^{-1}\right), \mathrm{NaHCO}_{3}\left(16 \mathrm{mg} \mathrm{L}^{-1}\right), \mathrm{Na}_{2}$ EDTA $\left(23 \mathrm{mg} \mathrm{L}^{-1}\right), \mathrm{H}_{3} \mathrm{BO}_{3}\left(2.48 \mathrm{mg} \mathrm{L}^{-1}\right), \mathrm{MnCl} \times 4 \mathrm{H}_{2} \mathrm{O}\left(1.4 \mathrm{mg} \mathrm{L}^{-1}\right),\left(\mathrm{NH}_{4}\right)_{6} \mathrm{Mo}_{7} \mathrm{O}_{24} \times 4 \mathrm{H}_{2} \mathrm{O}$ $\left(1.0 \mathrm{mg} \mathrm{L}^{-1}\right)$, cyanocobalamin $\left(0.04 \mathrm{mg} \mathrm{L}^{-1}\right)$, thiamine hydrochloride $\left(0.04 \mathrm{mg} \mathrm{L}^{-1}\right)$, biotin $\left(0.04 \mathrm{mg} \mathrm{L}^{-1}\right), \mathrm{Na}_{2} \mathrm{SiO}_{3} \times 5 \mathrm{H}_{2} \mathrm{O}\left(42.6 \mathrm{mg} \mathrm{L}^{-1}\right)$, and $\mathrm{FeCl}_{3}\left(1.6 \mathrm{mg} \mathrm{L}^{-1}\right)$. The $12 / 12 \mathrm{~h}$ day/night light cycle was provided by luminescent bulbs with a photon flux density of $\sim 200 \mu \mathrm{E} \mathrm{m}^{-2} \mathrm{~s}^{-1}$. Biomass sampling was carried out over $12 \mathrm{~h}, 24 \mathrm{~h}$, and 14 days.

\subsection{Anionic Surfactant Analysis by Spectrophotometric Determination}

Anionic surfactants were analyzed as a complex with methylene blue dye. Linear alkylbenzene sulphonate (LAS) mixture was used as an external standard. The calibration equation $y=3.0423 x+0.0041\left(R^{2}=0.9933\right)$ was obtained in the range of concentrations from 2 to $100 \mu \mathrm{g} \mathrm{L}{ }^{-1}$. LAS were extracted from the $0.05 \mathrm{~L}$ water samples with trichloromethane ( $5 \mathrm{~mL} \times 2 \mathrm{~min}$ ). All water samples passed through cellulose acetate filters $(45 \mu \mathrm{m}$, VLADiSART, Russia) using the filter-apparatus (Duran Group, Germany) to separate suspended matter on filters. Preliminary extraction of surfactants absorbed on suspended matter such as phytoplankton was carried out with ethanol $(1 \mathrm{~mL} \times 2 \mathrm{~min})$. Both soluble and absorbed surfactants were involved in the extraction. Absorbance was measured using a Cintra-20 spectrophotometer with quartz quvettes (path length of $1 \mathrm{~cm}$ ). The methylene blue and anionic surfactant complex has a maximum absorbance at $651.5 \mathrm{~nm}$.

\section{Results}

\subsection{Baikal Phytoplankton Composition}

Microscopy data revealed that the S. acus diatom dominated most samples of littoral and pelagic Baikal phytoplankton during the spring seasons of 2014, 2016, 2018, and 2020. The composition of Baikal phytoplankton (2020) is presented in Table 1. 
Table 1. Comprehensive composition of the current spring season phytoplankton in Lake Baikal (2020).

\begin{tabular}{|c|c|c|c|c|c|c|c|c|c|c|}
\hline \multirow{6}{*}{ Algae Taxa } & \multicolumn{10}{|c|}{ Sample Stations in South Basin of the Lake } \\
\hline & \multicolumn{2}{|c|}{$\begin{array}{c}\text { Western Flank } \\
\text { Nearshore } \\
\text { Sampling } \\
\text { Site No. } 19\end{array}$} & \multicolumn{6}{|c|}{ Pelagic Sampling Site No. 20} & \multicolumn{2}{|c|}{$\begin{array}{c}\text { Eastern Flank } \\
\text { Nearshore } \\
\text { Sampling Site } \\
\text { No. } 14\end{array}$} \\
\hline & \multicolumn{10}{|c|}{ Sampling Depth } \\
\hline & \multicolumn{2}{|c|}{$1 \mathrm{~m}$} & \multicolumn{2}{|c|}{$1 \mathrm{~m}$} & \multicolumn{2}{|c|}{$50 \mathrm{~m}$} & \multicolumn{2}{|c|}{$400 \mathrm{~m}$} & \multicolumn{2}{|c|}{$1 \mathrm{~m}$} \\
\hline & \multicolumn{10}{|c|}{ Number of cells $\mathrm{N}, 10^{3}$ cells $\mathrm{L}^{-1}$ and cell biomass $\mathrm{B}, \mathrm{mg} \mathrm{m}^{-3}$} \\
\hline & $\mathrm{N}$ & $\mathrm{B}$ & $\mathrm{N}$ & B & $\mathrm{N}$ & B & $\mathrm{N}$ & $\mathrm{B}$ & $\mathrm{N}$ & $\mathrm{B}$ \\
\hline \multicolumn{11}{|c|}{ Class Cyanophyta } \\
\hline Anabaena sp. & - & - & - & - & 3.4 & 0.34 & - & - & - & - \\
\hline Oscillatoria sp. & 42 & 5.9 & - & - & - & - & - & - & - & - \\
\hline Lyngbya sp. & - & - & - & - & - & - & - & - & - & - \\
\hline Phormidium sp. & - & - & - & - & - & - & - & - & - & - \\
\hline Total & 42 & 5.9 & - & - & 3.4 & 0.3 & - & - & - & - \\
\hline \multicolumn{11}{|c|}{ Class Chrysophyta } \\
\hline Dinobryon cylindricum O.E. Imhof & 0.2 & 0.4 & 0.3 & 0.6 & 1.4 & 2.7 & 2.5 & 4.8 & 0.4 & 0.20 \\
\hline Cystes of Chrysophyta & 0.6 & 0.3 & 0.6 & 0.3 & 1.4 & 0.7 & 6.5 & 3.3 & - & - \\
\hline $\begin{array}{l}\text { Dinobryon sociale (Ehrenberg) } \\
\text { Ehrenberg }\end{array}$ & - & - & - & - & - & - & - & - & - & - \\
\hline Mallomonas vannigera Asmund & - & - & - & - & - & - & - & - & 98 & 4.9 \\
\hline Chrysochromulina parva Lackey & 58 & 2.9 & 42 & 2.1 & 8.4 & 0.4 & 0.5 & 0.03 & - & - \\
\hline Total & 59 & 3.6 & 43 & 3.0 & 11 & 3.8 & 10 & 8.0 & 98 & 5.1 \\
\hline \multicolumn{11}{|c|}{ Class Cryptophyta } \\
\hline $\begin{array}{l}\text { Rhodomonas pusilla (H. } \\
\text { Bachmann) Javornicky }\end{array}$ & 65 & 16 & 26 & 6.3 & 17 & 4.0 & 2.2 & 0.5 & 145 & 35 \\
\hline Cryptomonas gracilis Skuja & 0.4 & 0.8 & 0.6 & 1.2 & 1.1 & 2.2 & 0.5 & 1.1 & 0.6 & 1.2 \\
\hline Cryptomonas ovata Ehrenberg & - & - & - & - & - & - & - & - & - & - \\
\hline Total & 65 & 16 & 27 & 7.5 & 18 & 6.3 & 2.7 & 1.6 & 146 & 36 \\
\hline \multicolumn{11}{|c|}{ Class Dinophyta } \\
\hline $\begin{array}{l}\text { Gyrodinium helveticum (Penard) Y. } \\
\text { Takano and T. Horiguchi }\end{array}$ & 0.4 & 10 & 0.9 & 23 & 2.3 & 58 & 1.1 & 28 & 0.4 & 11 \\
\hline $\begin{array}{l}\text { Gymnodinium baicalense N.L. } \\
\text { Antipova }\end{array}$ & 0.2 & 6 & 0.15 & 4.5 & - & - & - & - & 0.20 & 6.0 \\
\hline $\begin{array}{l}\text { Peridinium baicalense Kisselev and } \\
\text { V. Zvetkov }\end{array}$ & - & - & - & - & - & - & - & - & - & - \\
\hline Glenodinium sp. & 0.4 & 0.6 & 0.9 & 1.3 & 1.1 & 1.7 & 2.7 & 4.1 & 1.4 & 2.0 \\
\hline $\begin{array}{l}\text { Ceratium hirundinella } \\
\text { (O.F.Müller) Dujardin }\end{array}$ & - & - & - & - & - & - & - & - & - & - \\
\hline Total & 1.0 & 17 & 1.9 & 28 & 3.4 & 59 & 3.8 & 32 & 2.0 & 19 \\
\hline \multicolumn{11}{|c|}{ Class Bacillariophyta } \\
\hline $\begin{array}{l}\text { Aulacoseira baikalensis } \\
\text { (Wislouch) Simonsen }\end{array}$ & 0.4 & 6 & - & - & 0.3 & 4.5 & 0.5 & 8.1 & 3.2 & 48 \\
\hline $\begin{array}{l}\text { Aulacoseira islandica (O.Müller) } \\
\text { Simonsen + spore }\end{array}$ & 0.8 & 4 & 0.6 & 3 & 2 & 10 & 3.8 & 19 & 34 & 170 \\
\hline
\end{tabular}


Table 1. Cont.

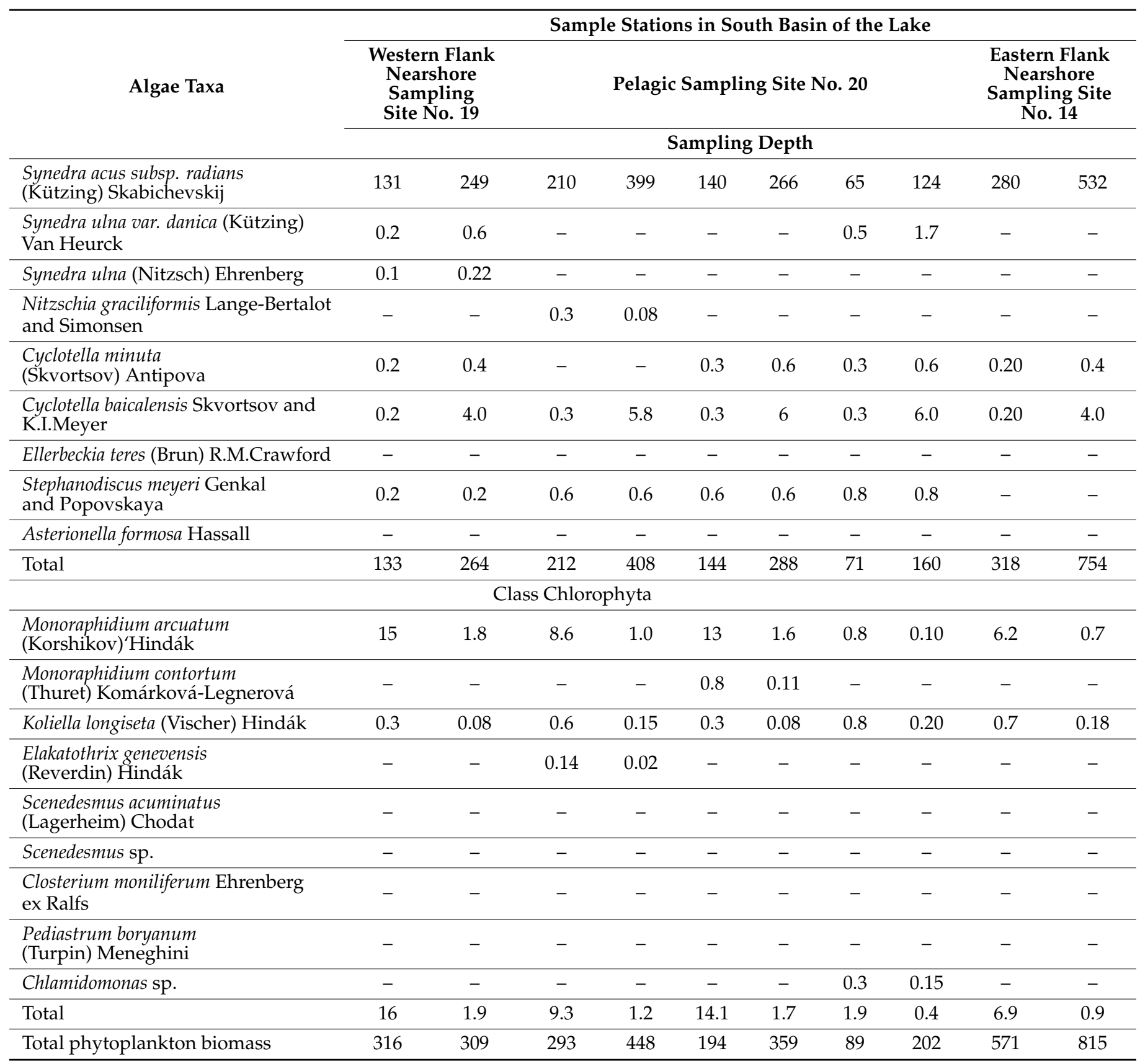

In all sedimentation samples of littoral and pelagic phytoplankton (2014, 2016-2021), S. acus subsp. radians dominated. Six algal classes represented the phytoplankton composition of sedimentation samples: Cyanophyta, Chrysophyta, Cryptophyta, Dinophyta, Bacillariophyta, and Chlorophyta (Table 2). As shown, Bacillariophyta were dominant during the spring season, with biomass values from $79 \%$ in deep water to $93 \%$ in surface water.

All net samples of littoral and pelagic phytoplankton contained S. acus as a dominant species in 2014 and 2016. S. acus contribution to total biomass was $~ 95 \%$, excluding smallcelled phytoplankton. The large-volume algae (Figure 2) A. baicalensis, Aulacoseira islandica (O. Müller) Simonsen and Ceratium hirundinella (O.F. Müller) Dujardin, long-size Synedra ulna (Nitzsch) Ehrenberg and Synedra ulna var. danica (Kützing) Van Heurck, small-volume Cyclotella baicalensis Skvortsov and K.I. Meyer and Cyclotella minuta (Skvortsov) Antipova, both of which may form long chains, and Dinobryon cylindricum O.E. Imhof, all contributed less than $5 \%$ to the total biomass of net phytoplankton. 
Table 2. Contribution of Bacillariophyta to total phytoplankton biomass during spring season (2020).

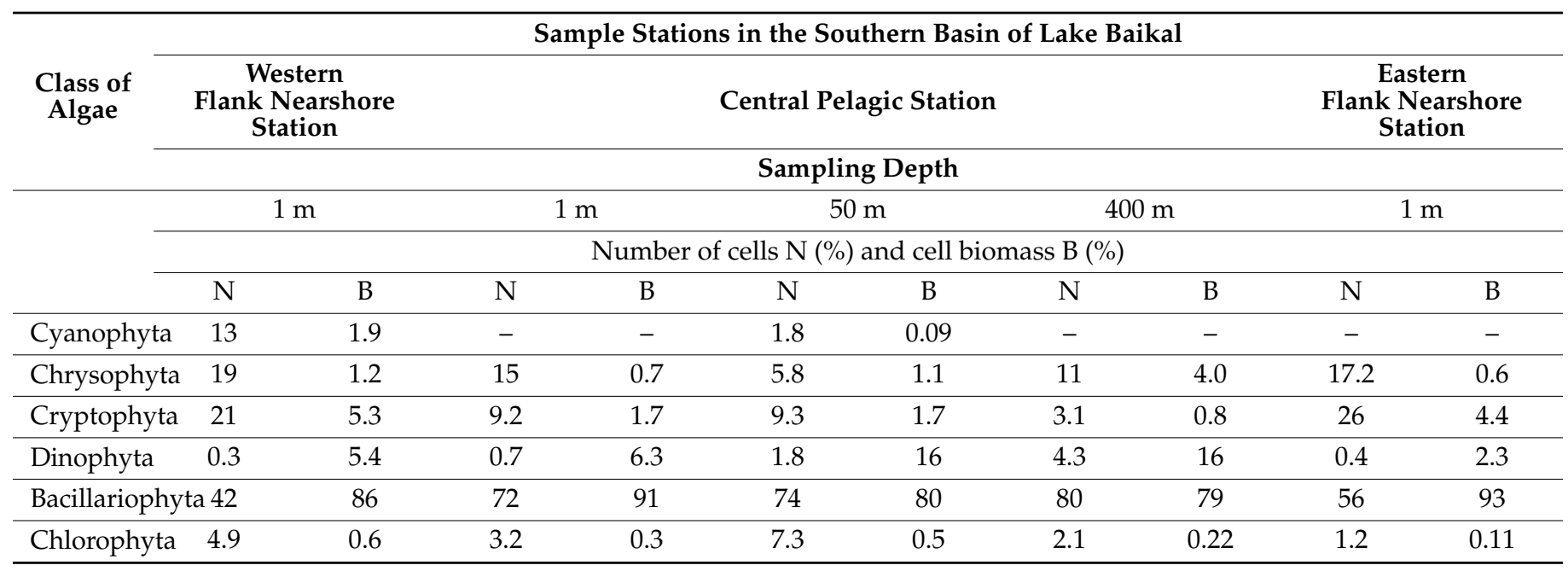

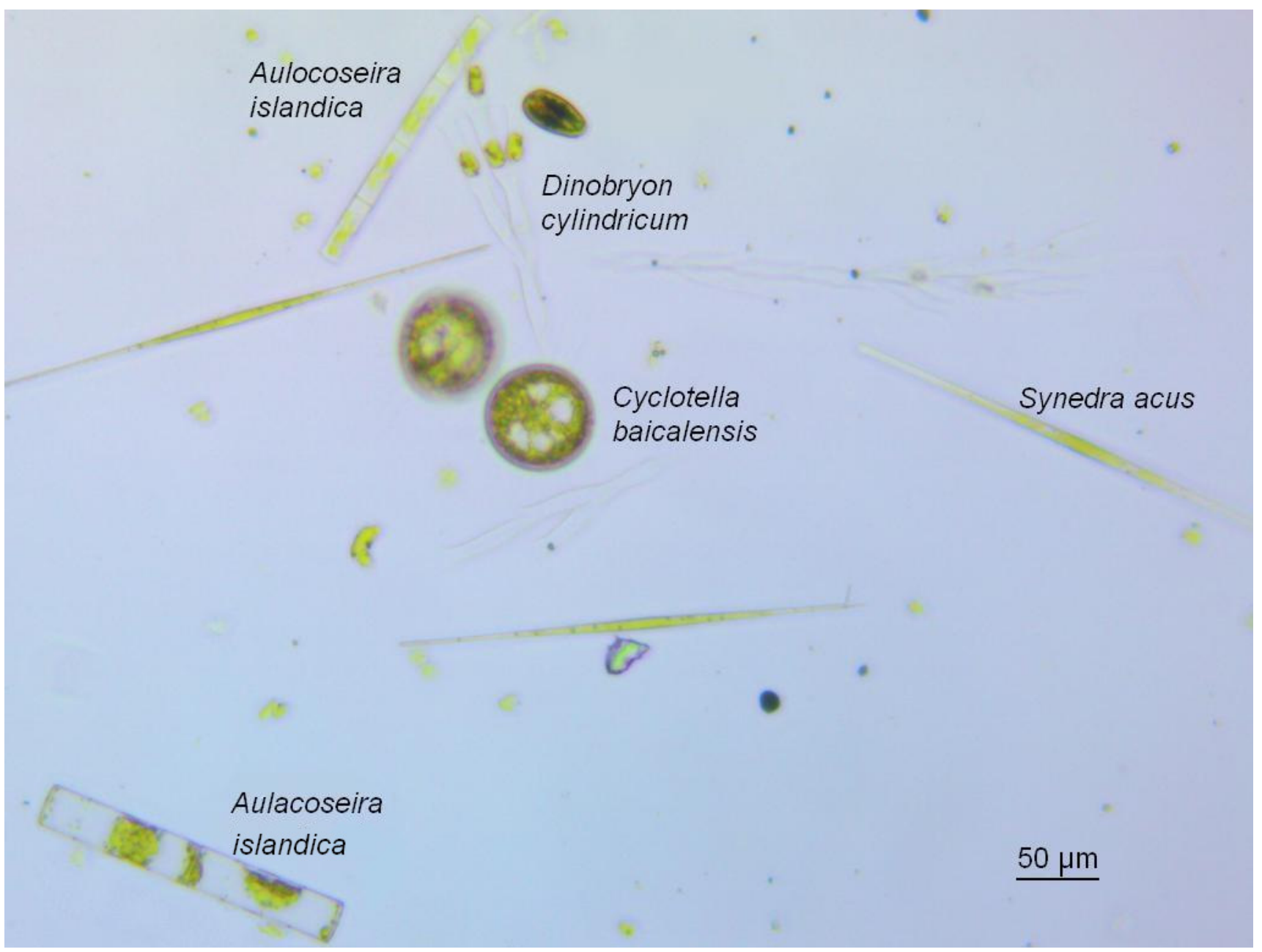

Figure 2. Some large-volume and long-sized algae in phytoplankton of Lake Baikal during the spring season 2020. Sample site no. 20.

The compositions of net samples and sedimentation samples were different. All sedimentation samples of littoral and pelagic phytoplankton contained S. acus as a dominant species in 2014 and 2016. S. acus contribution to the total biomass was up to 95\% (Table 3). 
Table 3. Contribution of S. acus to total coastal phytoplankton biomass during spring season (2014).

\begin{tabular}{ccccc}
\hline $\begin{array}{c}\text { Sampling } \\
\text { Stations }\end{array}$ & $\begin{array}{c}\text { Northern } \\
\text { Latitude (N) }\end{array}$ & $\begin{array}{c}\text { Eastern } \\
\text { Longitude (E) }\end{array}$ & $\begin{array}{c}\text { B (\%) of } \\
\text { S. acus }\end{array}$ & $\begin{array}{c}\text { Other Predominant } \\
\text { Bacillariophyta }\end{array}$ \\
\hline 0 & $51^{\circ} 31^{\prime} 391^{\prime \prime}$ & $104^{\circ} 11^{\prime} 398^{\prime \prime}$ & 91 & $\begin{array}{l}\text { A. baicalensis, C. baicalensis, } \\
\text { A. islandica }\end{array}$ \\
\hline 1 & $51^{\circ} 43^{\prime} 147^{\prime \prime}$ & $103^{\circ} 42^{\prime} 964^{\prime \prime}$ & 95 & $\begin{array}{l}\text { A. baicalensis, C. baicalensis, } \\
\text { A. islandica }\end{array}$ \\
\hline 2 & $51^{\circ} 31^{\prime} 726^{\prime \prime}$ & $104^{\circ} 08^{\prime} 086^{\prime \prime}$ & 91 & $\begin{array}{l}\text { A. baicalensis, C. baicalensis, } \\
\text { A. islandica }\end{array}$ \\
\hline 3 & $51^{\circ} 31^{\prime} 726^{\prime \prime}$ & $104^{\circ} 08^{\prime} 086^{\prime \prime}$ & 91 & $\begin{array}{l}\text { A. baicalensis, C. baicalensis, } \\
\text { A. islandica }\end{array}$ \\
\hline 5 & $52^{\circ} 47^{\prime} 332^{\prime \prime}$ & $106^{\circ} 36^{\prime} 445^{\prime \prime}$ & 85 & A. islandica \\
\hline 6 & $53^{\circ} 12^{\prime} 316^{\prime \prime}$ & $107^{\circ} 19^{\prime} 587^{\prime \prime}$ & 87 & A. islandica \\
\hline 7 & $53^{\circ} 13^{\prime} 201^{\prime \prime}$ & $107^{\circ} 22^{\prime} 290^{\prime \prime}$ & 87 & A. islandica \\
\hline 8 & $54^{\circ} 32^{\prime} 285^{\prime \prime}$ & $108^{\circ} 39^{\prime} 814^{\prime \prime}$ & 89 & A. baicalensis, A. islandica \\
\hline 9.1 & $55^{\circ} 21^{\prime} 428^{\prime \prime}$ & $109^{\circ} 12^{\prime} 713^{\prime \prime}$ & 88 & A. baicalensis, A. islandica \\
\hline 9.1 & $55^{\circ} 35^{\prime} 385^{\prime \prime}$ & $109^{\circ} 20^{\prime} 720^{\prime \prime}$ & 88 & A. baicalensis, A. islandica \\
\hline 19 & $55^{\circ} 34^{\prime} 021^{\prime \prime}$ & $109^{\circ} 13^{\prime} 677^{\prime \prime}$ & 88 & A. baicalensis, A. islandica \\
\hline $51^{\circ} 49^{\prime} 094^{\prime \prime}$ & $104^{\circ} 54^{\prime} 776^{\prime \prime}$ & 95 & $\begin{array}{l}\text { A. baicalensis, C. baicalensis, } \\
\text { A. islandica }\end{array}$ \\
\hline
\end{tabular}

\subsection{Statistical Analysis}

The comparative statistical analysis of data on FA content in the samples of the axenic culture of S. acus and natural plankton dominated by S. acus using the principal component method is shown in Figure 3. This method takes into account a high number of individual FAs in every sample. It allows us to visualize data through the conversion of the multidimensional space to a two-dimensional one. As the principal components, we selected FAs of different saturations and chain lengths (1-22 carbon atoms). These FAs are $\mathrm{C} 16: 0, \mathrm{C} 16: 1(\omega-7), \mathrm{C} 16: 2(\omega-4), \mathrm{C} 16: 3(\omega-4), \mathrm{C} 18: 0, \mathrm{C} 18: 1(\omega-9), \mathrm{C} 18: 3(\omega-3), \mathrm{C} 18: 4(\omega-3)$, C20:4( $\omega-6), C 20: 5(\omega-3)$, and C22:6( $\omega-3)$. Of total FA weight, $70-80 \%$ belongs to these FAs. Percentages of the aforementioned FAs in laboratory culture biomass at stationary and exponential phases of growth, as well as in the coastal (no. 1 to 9) and pelagic phytoplankton samples (no. 10 to 17), were chosen as variables in the data array. Three separate projections to the factor plane were made for laboratory culture (Figure 3, top), coastal phytoplankton (Figure 4, bottom left), and pelagic phytoplankton variables (Figure 3, bottom right). The significant validity $(\geq 90 \%)$ of presented results was marked for all three cases. Based on analysis of the FA composition of the laboratory culture determined by this statistical method, differences are clear for diatoms at stationary and exponential growth phases (Figure 3, top).

The vectors of most samples of the coastal Baikal phytoplankton lie in the upper left-half plane, except for samples no. 4,6, and 8. This figure demonstrates the significant difference between the nearshore samples no. 4,6, and 8 from the cities and other coastal samples. 


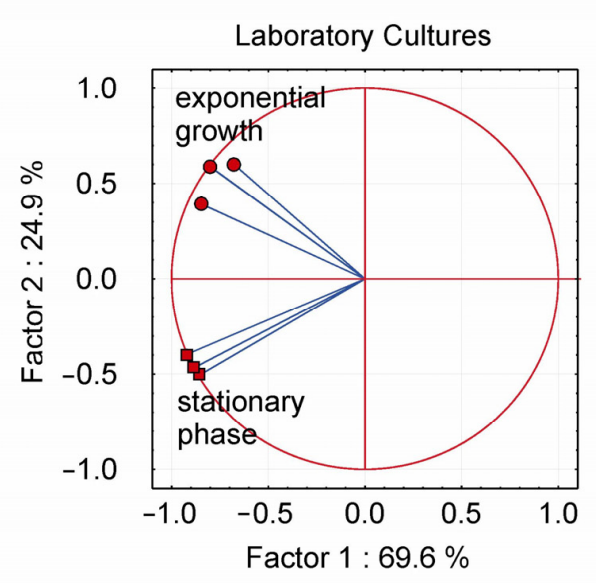

Lake Baikal Coastal Phytoplankton

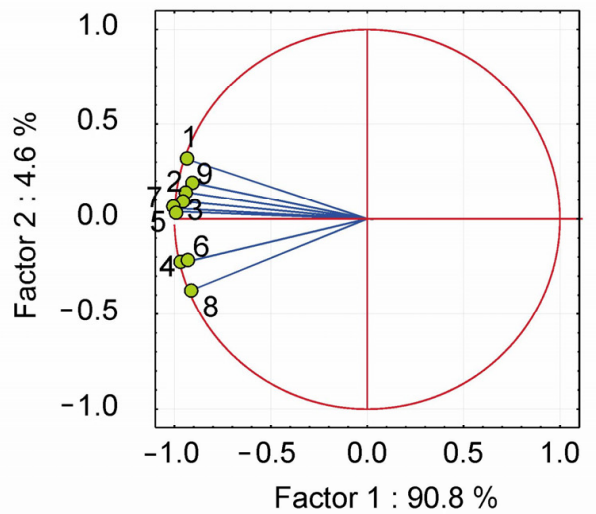

Legend:

- S. acus laboratory culture at exponential phase of growth

- S. acus laboratory culture at stationary phase of growth

- Lake Baikal phytoplankton, collected at the coastal stations

- Lake Baikal phytoplankton, collected at the pelagic stations, located about $3 \mathrm{~km}$ from the shore

- Lake Baikal phytoplankton, collected at the central pelagic stations of the maximal depth and far from shore

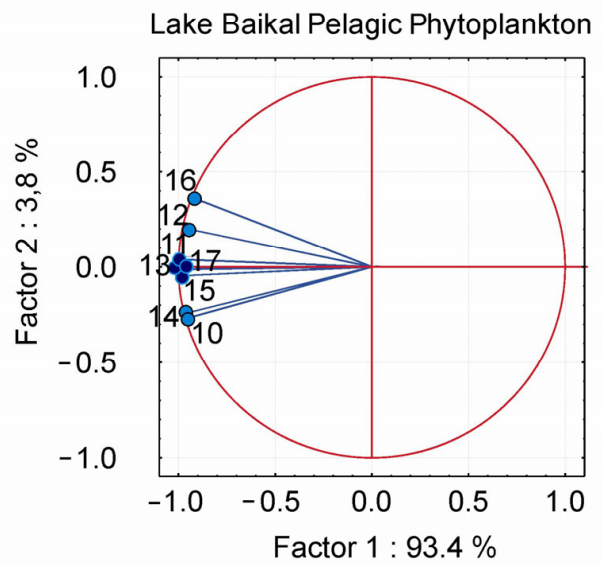

Figure 3. Analysis of Baikal phytoplankton and S. acus axenic laboratory culture by the principal component method.

Considering that samples were collected at the spring blooming peak, we can explain with relative confidence the positioning of vectors for the samples of coastal phytoplankton (Figure 3, bottom left), which is similar to that of vectors for laboratory culture samples at the stage of exponential growth. Concerning pelagic Baikal phytoplankton, the maximum closeness between FA compositions of the samples from central pelagic stations no. 11, 13, 15 , and 17 that were maximally remote from the shore is noteworthy. FA composition of these central samples differed from offshore pelagic ones.

Cluster analysis of the samples is presented (Figure 4). There are two main clusters of the samples, which do not cross. Laboratory culture samples at the stage of exponential growth are clustered together with pelagic samples and the bulk of coastal samples. This can be explained by the fact that during the sampling of natural phytoplankton, all stations were at the stage of intensive cell division. Moreover, it is also obvious that the pelagic plankton samples and the bulk of the coastal plankton samples form the two main clusters and show clear differences in FA composition of coastal and pelagic plankton (Figure 4). 


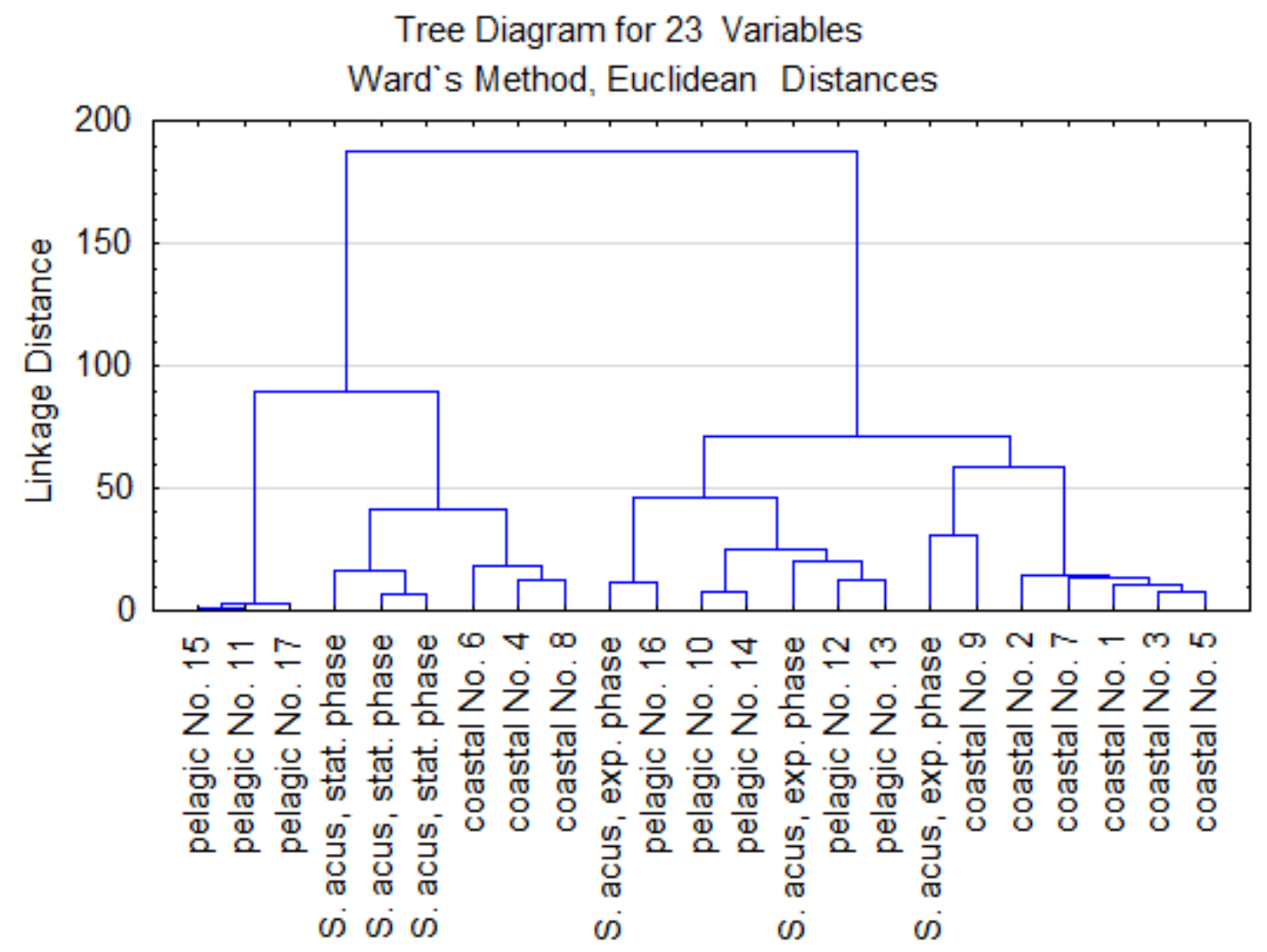

Figure 4. Dendrogram of the FA composition of the Baikal coastal and pelagic phytoplankton and the FA composition of the $S$. acus laboratory culture at stationary and exponential phases of growth.

The difference between the phytoplankton from the central pelagic stations and the offshore pelagic stations is possibly related to the distance from the shore. Stations no. 11, 13,15 , and 17 were located in the central area of the lake in contrast to stations no. 10, 12,14 , and 16, which were located at a distance of $3 \mathrm{~km}$ from the shore (Figures 1 and 4 ). Some pelagic and coastal samples clustered together with laboratory culture samples at the stationary phase (Figure 4). This suggests that at these stations, natural phytoplankton were the same as at the stationary phase, which contradicts the microscopy data. Therefore, it is necessary to carefully compare the results of laboratory experiments and those of natural phytoplankton. Data analysis using the principal component method and the cluster analysis method is related to the so-called exploring analysis. This allows us to find dependencies in the analysis of large data arrays, but their interpretation is beyond the scope of mathematical statistics [53].

\subsection{FA Composition and FA Peroxidation Product Analysis}

In our study, we analyzed the FA composition and TBARS concentration in natural phytoplankton as well as in laboratory culture of $S$. acus. Total FA content in the pelagic and nearshore phytoplankton samples (2014 and 2016) varied from $20-60 \mathrm{mg} \mathrm{g}^{-1}$ of dry weight (d.w.). Myristic C14:0, palmitic C16:0, and oleic C18:0 acids were dominant saturated FAs (SFAs) of $\sim 30-40 \%$. Palmitoleic acid C16:1(n-7) was the dominant MUFA ( 20-30\%). Hexatrienoic C16:3(n-6,9,12) and essential eicosapentaenoic C20:5(n-5,8,11,14,17) acids were dominant PUFAs ( 30-40\%). For all samples, high contents of C16:1 and C16:0 FAs (26-48\%), as well as of C20:5 $\omega-3$ FA (13-23\%), were observed (Table 4). 
Table 4. FA content averages of natural phytoplankton and laboratory culture of S. acus.

\begin{tabular}{|c|c|c|c|c|c|c|c|}
\hline \multirow[b]{3}{*}{ FAs } & \multicolumn{7}{|c|}{ FA Composition, $\%$} \\
\hline & \multicolumn{4}{|c|}{ Phytoplankton Sampling Stations } & \multicolumn{3}{|c|}{ Laboratory S. acus Culture } \\
\hline & $\begin{array}{l}\text { Nearshore } \\
\text { Stations Far } \\
\text { from } \\
\text { Settlements }\end{array}$ & $\begin{array}{l}\text { Central } \\
\text { Pelagic } \\
\text { Stations }\end{array}$ & $\begin{array}{l}\text { Nearshore } \\
\text { Stations Near } \\
\text { Settlements }\end{array}$ & $\begin{array}{l}\text { Offshore } \\
\text { Pelagic } \\
\text { Stations }\end{array}$ & $4 \mathrm{~h}$ & $24 \mathrm{~h}$ & 2 Weeks \\
\hline C16:1 $\omega 9$ & 30.4 & 21.7 & 19.2 & 12.2 & 12.0 & 13.3 & 27.0 \\
\hline C16:0 & 17.3 & 11.4 & 17.4 & 13.6 & 37.2 & 36.1 & 21.0 \\
\hline $\mathrm{C} 16: 3 \omega 4$ & 5.5 & 14.2 & 4.5 & 10.8 & 4.8 & 6.0 & 8.4 \\
\hline $\mathrm{C} 16: 2 \omega 4$ & 3.6 & 4.3 & 2.9 & 4.7 & 2.2 & 2.9 & 3.9 \\
\hline C18:1 $\omega 9$ & 2.3 & 1.9 & 2.3 & 0.7 & 5.6 & 5.4 & 1.7 \\
\hline C18:0 & 5.1 & 1.5 & 5.1 & 12.8 & 19 & 16 & 5.5 \\
\hline C18:4 $\omega 3$ & 2.4 & 0.2 & 2.4 & 0.8 & 1.65 & 2.11 & 2.4 \\
\hline C18:3 $\omega 3$ & 1.7 & 0.3 & 1.7 & 0.5 & 1.55 & 1.33 & 1.04 \\
\hline C20:4 w6 & 0.3 & 0.3 & 0.1 & 0.3 & 0.08 & 0.05 & 0.02 \\
\hline C20:5 $\omega 3$ & 12.9 & 23.0 & 13.3 & 14.6 & 6.6 & 8.9 & 13.0 \\
\hline C22:6 63 & 3.8 & 1.7 & 2.0 & 3.7 & 0.59 & 1.02 & 1.27 \\
\hline PUFAs & 30.3 & 44.1 & 27.6 & 35.4 & 10.1 & 14.7 & 31.9 \\
\hline PUFAs + MUFAs * & 65 & 72 & 53 & 50 & 37 & 43 & 68 \\
\hline
\end{tabular}

The most similar FA compositions were observed for nearshore phytoplankton collected far from settlements and S. acus cultivated at $6{ }^{\circ} \mathrm{C}$ in poor medium during the two-week period (Table 4). The maximum content of polyunsaturated FAs (PUFAs) and monounsaturated FAs (MUFAs), including essential C20:5 w3 eicosapentaenoic acid, was recorded in pelagic phytoplankton from the central stations (Table 3).

The formation of malondialdehyde (MDA) as an FA peroxidation product characterizes pathological processes in a living cell. MDA can appear in water organisms under the impact of anionic surfactants, such as linear alkylbenzene sulphonates (LASs) [41,42,54], heavy metals [55], polycyclic aromatic hydrocarbons (PAH) [56], and antibiotics [57]. According to a previous investigation [58], anionic surfactants found in the Baikal nearshore water ranged from $4.8 \mu \mathrm{g} \mathrm{L}^{-1}$ to $20 \mu \mathrm{g} \mathrm{L}^{-1}$ [58]. Low concentrations of LASs $\left(5-20 \mu \mathrm{g} \mathrm{L}^{-1}\right)$ can cause toxic effects on aquatic microorganisms [59-61].

Based on these data, we analyzed for the first time the lipid peroxidation marker in Lake Baikal phytoplankton and laboratory cultures of $S$. acus. In phytoplankton collected from central pelagic stations no. 11,13,15,17, and 18 and at nearshore stations no. 4 and 8 , TBARS were not detected (Table 5). In phytoplankton of nearshore station no. 6, TBARS were represented a minimal concentration ( $14 \mu \mathrm{g} \mathrm{g}^{-1}$ of d.w.). TBARS concentration in phytoplankton of other nearshore stations near the Kultuk settlement, as well as near towns of Baikalsk and Severobaikalsk, ranged from $80-340 \mu \mathrm{g} \mathrm{g}^{-1}$ of d.w. TBARS were either not found or represented a minimal concentration in samples with high PUFA and MUFA percentages of $\sim 70 \%$. A TBARS concentration of $\geq 80 \mathrm{\mu g} \mathrm{g}^{-1}$ was identified in samples with an average PUFA and MUFA content of $53 \mu \mathrm{g} \mathrm{g}^{-1}$ of d.w. In the $S$. acus laboratory culture, both at exponential and stationary stages of growth, TBARS were not detected (Table 5). 
Table 5. TBARS concentrations ( $\mu \mathrm{g} \mathrm{g}^{-1}$ of d.w.) in some phytoplankton samples collected in 2016.

\begin{tabular}{|c|c|c|c|c|c|}
\hline Samples & Location & $\begin{array}{l}\text { Lake } \\
\text { Zone }\end{array}$ & $\begin{array}{l}\text { Total FA, } \\
\text { mg g }^{-1}\end{array}$ & $\begin{array}{c}\text { PUFA and } \\
\text { MUFA } \\
\text { Percentage }\end{array}$ & $\begin{array}{c}\text { TBARS, } \\
\mu \mathrm{g}^{-1} \text { of d.w. }\end{array}$ \\
\hline 11 & Marituy River-Solzan River (2016) & Pelagic & $15.8 \pm 1.4$ & 72 & Not found \\
\hline 17 & $\begin{array}{l}\text { Baikalskoe settlement-Frolikha } \\
\text { River (2016) }\end{array}$ & Pelagic & $17.0 \pm 1.5$ & 72 & Not found \\
\hline 18 & Elokhin Cape-Davsha settlement & Pelagic & $24.2 \pm 2.2$ & 70 & Not found \\
\hline 1 & Kultuk settlement (2016) & Nearshore & $24.0 \pm 2.1$ & 56 & 80 \\
\hline 1 & Kultuk settlement (2018) & Nearshore & $20.7 \pm 1.8$ & 56 & 100 \\
\hline 2 & Baikalsk town (2016) & Nearshore & $27.1 \pm 2.4$ & 58 & 280 \\
\hline 3 & Baikalsk town (2016) & Nearshore & $27.1 \pm 2.4$ & 58 & 340 \\
\hline 0 & Baikalsk pulp and paper mill (2016) & Nearshore & $26.2 \pm 2.3$ & 60 & 160 \\
\hline 0 & Baikalsk pulp and paper mill (2018) & Nearshore & $21.3 \pm 1.9$ & 54 & 164 \\
\hline 4 & Aya Bay (2016) & Nearshore & $28.1 \pm 2.5$ & 66 & Not found \\
\hline 6 & Shamanka Bay (2016) & Nearshore & $28.7 \pm 2.6$ & 60 & 14 \\
\hline 7 & Elokhin Cape (2016) & Nearshore & $18.1 \pm 1.6$ & 55 & 180 \\
\hline 8 & Baikalskoe settlement (2016) & Nearshore & $49 \pm 4$ & 68 & Not found \\
\hline 9.1 & Tyya River mouth (2016) & Nearshore & $26.7 \pm 2.4$ & 46 & 100 \\
\hline 9.1 & Tyya River mouth (2018) & Nearshore & $15.6 \pm 1.4$ & 58 & 11 \\
\hline 9.2 & Senogda Bay (2016) & Nearshore & $14.0 \pm 1.3$ & 40 & 190 \\
\hline \multicolumn{3}{|c|}{ S. acus laboratory culture, $+6^{\circ} \mathrm{C}, \mathrm{DM}$ medium, $12 \mathrm{~h}$} & $4.2 \pm 0.4$ & 48 & Not found \\
\hline \multicolumn{3}{|c|}{ S. acus laboratory culture, $+6^{\circ} \mathrm{C}, \mathrm{DM}$ medium, $24 \mathrm{~h}$} & $35 \pm 3$ & 74 & Not found \\
\hline \multicolumn{3}{|c|}{ S. acus laboratory culture, $+6^{\circ} \mathrm{C}$, DM medium, 50 days } & \multicolumn{2}{|c|}{ No data } & Not found \\
\hline
\end{tabular}

\section{Discussion}

\subsection{The Present Composition of Baikal Phytoplankton during the Spring Season}

Previously, it was thought that during the spring season the algal complex of pelagic phytoplankton in Lake Baikal consisted predominantly of large-volume diatoms [44], such as endemic Aulacoseira baicalensis (Wislouch) Simonsen, A. islandica (O.Müller) Simonsen, Cyclotella minuta (Skvortzov) Antipova, endemic Cyclotella baicalensis Skvortzov et Meyer; S. acus subsp. radians (Kützing) Skabitschevsky, and Stephanodiscus meyeri Genkal et Popovskaya. A similar phytoplankton composition is typical of pelagic and coastal zones [54-56]. Notably, for the past period ( 30 years), the structure and functioning of shallow spring phytoplankton have changed. The periodicity of years with high productivity $\left(B \geq 1000 \mathrm{mg} \mathrm{m}^{-3}\right)$ and low productivity $\left(B \leq 100 \mathrm{mg} \mathrm{m}^{-3}\right)$ of large-volume $A$. baicalensis has disappeared [62,63]. In the last ten years, the small-volume diatom S. acus subsp. radians has been maximally abundant during each spring season. Phytoplankton productivity in the current period from 2014 to 2021 was much lower than in previous years (1950-1970 and 1970-1995) when large-cell diatoms of the genus Aulacoseira predominated $[12,63,64]$. In recent years, $A$. baicalensis has been found as single cells without intensive blooming.

Our data show that in all littoral and pelagic net samples, phytoplankton (2016-2020) containing S. acus, prevailed. This allows us to compare the FA composition of S. acus fraction of coastal and pelagic phytoplankton exposed to anthropogenic impacts of varying intensity. The dominance of S. acus is needed to compare the results of FA analysis of the samples collected within different parts of the lake. This is due to $S$. acus prevalence and its sensitivity to pollution. We found that $S$. acus is a bioindicator of anionic surfactant pollution - it responds to the exposure of anionic surfactants of 5-20 $\mathrm{g} \mathrm{L} \mathrm{L}^{-1}$ concentration. 
The response appears as oxidation stress due to a high content of PUFAs in cell membranes of diatoms. Diatom membranes consist of proteins and phospholipids ( $50 \% / 50 \%$ by mass) including PUFAs. For example, the PUFA content of $S$. acus cell membrane is $\sim 30 \%$. On the other hand, the cell membranes of Chrysophyta, Cryptophyta, Dinophyta, Cyanophyta, and Chlorophyta classes consist mostly of polymers. These polymers such as cellulose and hemicellulose make these algae more stress resistant.

Many lakes show vertical stratification of their water masses, at least for some extended periods. In Lake Baikal, we can observe inverse water stratification in March, with a surface water temperature of $\sim 0.4-2{ }^{\circ} \mathrm{C}$ [64]. In the deep-water layer, the water temperature is $\sim 3.6{ }^{\circ} \mathrm{C}$. At the end of May or in the first two weeks of June, we observed spring homothermy of the water body, during which water temperature is $\sim 3.5-3.7^{\circ} \mathrm{C}$ through all layers, from the bottom to the surface [65]. At the end of August or in the first two weeks of September, we can observe a reverse water stratification, in which surface water temperature is $\sim 10-12{ }^{\circ} \mathrm{C}$ and sometimes it may reach $14-22{ }^{\circ} \mathrm{C}$, deep-water temperature is $\sim 3.5-3.7^{\circ} \mathrm{C}$, and thermocline depth is $25-50 \mathrm{~m}$. At the end of November, an autumn homothermy can occur. In our study, all samples were collected during the spring season when water temperatures were near homothermy values [64].

In our investigation, water temperature ranged from $3.4-3.6^{\circ} \mathrm{C}$ at almost all pelagic sampling sites and from 3.0-6.0 ${ }^{\circ} \mathrm{C}$ at almost all coastal sites. Nitrate, phosphate, and silica concentrations in Baikal water are constant throughout the year $[10,19,66]$. According to Popovskaya et al., there is no clear relationship between the concentration of nutrients and phytoplankton growth [44]. The seasonal by-turn blooming of the different species is mostly due to temperature changes. The temperature during the spring season increases irregularly throughout the entire water area of the lake due to its large length from south to north. According to Popovskaya et al. [44], there is no clear relationship between the intensity of phytoplankton growth to water temperatures of $0.8^{\circ} \mathrm{C}$ to $5.0^{\circ} \mathrm{C}$. Hence, our study did not take into account water temperatures and nutrient concentrations that provide high productivity in coastal and pelagic zones $[10,21,25,26]$ and which cannot cause stress or change in phytoplankton FA composition under spring season homothermy.

\subsection{Phytoplankton FA Composition and FA Peroxidation}

At all sampling sites, phytoplankton were at the exponential stage of growth, allowing us to exclude the dependence of FA composition on growth stages. Multivariate analysis of the results by the principal component method and the cluster analysis confirms that FA composition of pelagic and coastal phytoplankton differs.

A higher PUFA concentration $(\sim 40 \%)$ was determined in the samples of pelagic phytoplankton compared to most of the coastal samples ( 26\%). Additionally, a higher content (up to 10-15\%) of MUFA of triacylglycerols was determined in the coastal samples. Higher concentrations of the sum of MUFA and PUFA $(\sim 65 \%)$ were detected in coastal samples no. 4, 6, and 8 compared to other coastal samples $(\sim 53 \%)$. We noted differences in PUFA concentrations between pelagic phytoplankton collected at the central stations and phytoplankton from the offshore pelagic stations. Trying to understand this difference, this study analyzed, for the first time, TBARS as a lipid peroxidation marker in Baikal phytoplankton and laboratory cultures of $S$. acus. Table 5 shows that TBARS were either not found or shows minimal concentrations in the coastal samples no. 4,6, and 8 samples. Aya Bay (station no. 4), Shamanka Bay (station no. 6), and Ludar Cape (Station no. 8), where the Baikalskoe settlement is situated (population 600 people), are the areas with low anthropogenic load compared to other nearshore stations. Oxidative stress was not identified at these stations. As mentioned above, the principal component method and cluster analysis revealed the clustering of these samples separately from other coastal samples (Figures 3 and 4).

Coastal stations no. 1, 2, 3, 5, and 9 were situated near large cities and settlements, such as Kultuk (3715 citizens, according to 2020 data), Baikalsk (12,534), Khuzhir (1350), and Severobaikalsk $(23,180)$. The high TBARS concentration in phytoplankton of these 
stations ranged from $80-340 \mu \mathrm{g} \mathrm{g}^{-1}$ of dry weight (Table 5). High TBARS concentration near Elokhin Cape can be explained by cyclonic convectional gradient flow along the perimeter of the lake, as this flow can transport water from the Severobaikalsk town (station no. 9) along the west coast to Elokhin Cape [23,67].

Therefore, we suggest that this phenomenon of TBARS occurrence in phytoplankton results from peroxidation of cell membrane phospholipids (mainly PUFAs) due to anthropogenic impact in the coastal zone. We assume that this impact can be caused by anionic surfactants. These substances were found in Lake Baikal for the first time in 2019 in our previous investigation [58]. According to the mentioned investigation, anionic surfactant concentrations in the coastal water of Lake Baikal ranged from $4.8 \mu \mathrm{g} \mathrm{L}{ }^{-1}$ (station no. 8) to $20 \mu \mathrm{g} \mathrm{L}{ }^{-1}$ (station no. 9). A higher concentration of linear alkylbenzene sulphonates LAS $\left(40 \mu \mathrm{g} \mathrm{L}^{-1}\right)$ was found in the Tyya River, a tributary of Lake Baikal. The Tyya mouth is located close to the station no. $9(\sim 3 \mathrm{~km})$. A dramatically high concentration of anionic surfactants $\left(170 \mu \mathrm{g} \mathrm{L}^{-1}\right)$ was registered in sewage water of Severobaikalsk (Republic of Buryatia) [57]. We also analyzed anionic surfactants in surface water of three basins $(n=57)$ using a modified spectrophotometry method with methylene blue and gas chromatography coupled with mass spectrometry. Surfactant concentrations ranged from $4.5 \pm 0.6$ to $29.2 \pm 3.5$. $\mu \mathrm{g} \mathrm{L}^{-1}$ in samples collected in autumn 2019, and from $2.00 \pm 0.24$ to $16.9 \pm 2.1 \mu \mathrm{g} \mathrm{L}{ }^{-1}$ in samples collected in spring season 2020. Maximum concentrations ( $\geq 20 \mu \mathrm{g} \mathrm{L}^{-1}, n=3$ ) were found in the recreation zones as well as in zones located not far from settlements.

There is no production plant at the coast of Lake Baikal dumping untreated sewage water into the lake. Nevertheless, the recreation and human impacts on the environment have increased significantly [68]. The dramatic effect relates to the absence of wastewater treatment plants on the Lake Baikal coast. Few treatment plants are of outdated design. As a result, eutrophication of local nearshore areas as well as the toxic effect of environmental pollutants of untreated sewage water can be observed. Anionic surfactants such as LASs are the most common aquatic pollutants. Low LAS concentrations $\left(5-20 \mu \mathrm{g} \mathrm{L}^{-1}\right)$ have toxic effects on aquatic microorganisms $[59,60]$ and fishes, leading to morphological changes in gills and skin [61]. Given this, we can assume a negative impact of low surfactant concentrations on Baikal phytoplankton. This phenomenon can cause changes in the production of biologically active substances including fatty acids that puts the biodiversity of the world's deepest lake at risk. Baikal is one of the largest and deepest lake of the world natural heritage of the UNESCO. It differs from other lakes by its unique marine features. A lot of fine poetic words like these "Hoc mare [Yonder is the sea], magnum et spatiosum manibus [great and wide]; illic reptilia quorum non est numerus [Wherein are things creeping innumerable], animalia pusilla cum magnis [Both small and great beasts]" can be dedicated to great lakes. But nearshore living organisms of great water ecosystems need our efficient actions to decrease anthropogenic impact on littoral. Phytoplankton represent the first link of the water ecosystem. Their damage by chemicals may result in serious biodiversity changes, the onset of which can already be observed in the nearshore zone.

\section{Conclusions}

For the first time, we revealed a lipid peroxidation product (TBARS) in the Baikal nearshore phytoplankton collected near large cities and settlements $\left(80-340 \mu \mathrm{g} \mathrm{g}^{-1}\right)$. TBARS were not detected in the phytoplankton of stations that were maximally remote from the sources of anthropogenic impact. Changes in fatty acid composition, including a decrease in PUFA, were identified for phytoplankton exposed to anthropogenic impact. This suggests that the high level of anthropogenic impact on the coastal zone near cities and large settlements causes stress of phytoplankton. 


\begin{abstract}
Author Contributions: Conceptualization, methodology, writing the text of the manuscript, translation-A.A.N.; editing-S.S.V.; chemical analysis of FAs, their peroxidation products, and surfactants-A.A.N.; cultivation of the S. acus-N.A.V., Y.P.G., S.M.S.; water temperature measurementsV.V.B., R.Y.G.; microscopic analysis of Lake Baikal phytoplankton composition (2018-2021) -S.S.V.; phytoplankton investigation (2014-2016)—S.M.S.; sampling of water-A.A.N., S.S.V.; sampling of phytoplankton-S.M.S., S.S.V., A.A.N.; statistical analysis-A.A.N., S.M.S., Y.S.B.; evaluation of the level of anthropogenic impact-A.A.N. The investigation is the authors' common cause. All authors have read and agreed to the published version of the manuscript.
\end{abstract}

Funding: The investigation was carried out within the State Projects of the Ministry of the Science and High Education of the Russian Federation (no. 0279-2021-0005 "Investigation of the transformation s in the states of water bodies and watercourses in East Siberia ... ", no. 0279-2021-0008 "From the cell to the ecosystem: investigation the ultrastructure of the hydrocoles ..." ", no. 0279-2021-0009 "Investigation of the role of selected genes and proteins of Baikal diatoms ... ").

Institutional Review Board Statement: Not applicable.

Informed Consent Statement: Not applicable.

Data Availability Statement: The data presented in this study are available on request from the corresponding author Alyona Nikonova. E-mail: alenaxis@list.ru.

Acknowledgments: The authors thank Andrey P. Fedotov, Igor B. Mizandrontsev, and Alexander G. Gorshkov for helpful advises. We are grateful to Mikhail A. Grachev and Elena V. Likhoshway for the "Ultramicroanalysis" Instrumental Center equipment. We acknowledge Tamara V. Khodzher and Irina I. Marinaite for the possibility of using GC-FID. We thank Andrey V. Khabuev for the Lake Baikal map-making, and the crew of R/V "Vereshchagin", "Papanin", "Koptyug", "Titov" for fieldwork made on Lake Baikal. Alyona Nikonova expresses deep gratitude to her family.

Conflicts of Interest: The authors declare no conflict of interest.

\title{
References
}

1. Schmid, M.; De Batist, M.; Granin, N.G.; Kapitanov, V.A.; McGinnis, D.F.; Mizandrontsev, I.B.; Obzhirov, A.I.; Wuest, A. Sources and sinks of methane in Lake Baikal: A synthesis of measurements and modeling. Limnol. Oceanogr. 2007, 52, $1824-1837$. [CrossRef]

2. De Batist, M.; Canals, M.; Sherstyankin, P.; Alekseev, S. The INTAS Project 99-1669 Team, 2002. A New Bathymetric Map of Lake Baikal. Available online: http:/ / www.lin.irk.ru/intas/index.htm (accessed on 6 December 2021).

3. Vereschagin, G.Y. Baikal; Gosudartvennoye Izdatel'stvo Geograficheskoi Literatury: Moscow, Russia, 1949; 228p. (In Russian)

4. Galazii, G.I. (Ed.) Baikal; Russian Academy of Sciences, Siberian Branch, Interdepartmental Scientific Board on "Siberia" Program, Federal Service of Geodesy and Cartography of Russia: Moscow, Russia, 1993; 160p. (In Russian)

5. Wetzel, R.G. Limnology: Lake and River Ecosystems, 3rd ed.; Academic Press: San Diego, CA, USA; San Francisco, CA, USA; New York, NY, USA; Boston, MA, USA; London, UK; Sydney, Australia; Tokyo, Japan, 2001; 1006p.

6. Nakashizuka, T.; Stork, N. (Eds.) Biodiversity Research Methods: YBOY (International Biodiversity Observation Year) in Western Pacific and Asia; University Press, Trans Pacific Press: Kyoto, Japan, 2002; 216p.

7. Karabanov, E.B. Podvodnye Ladshafty Baikala [Underwater Landscapes of Lake Baikal]; Nauka Publ.: Novosibirsk, Russia, $1987 ;$ p. 183. (In Russian)

8. Kozhov, M.M. Biologiya Ozera Baikal [Lake Baikal Biology]; Acad. of Sciences of USSR: Moscow, Russia, $1962 ;$ p. 316.

9. Lut, B.F. Morfologiya i morfometriya Baikalskoi vpadiny [Morphology and Morphometry of Baikal Depression], Chapter II. In The Way for knowledge of Baikal; Afanasieva, E.L., Beckman, M.Y., Bezrukova, E.V., Verbolov, V.I., Votintcev, K.K., Galazii, G.I., Goldyrev, G.S., Granina, L.Z., Dryukker, V.V., Ladeishokov, N.P., et al., Eds.; Nauka Publ.: Novosibirsk, Russia, 1987; pp. 34-47. (In Russian)

10. Votintsev, K.K.; Meshcheryakova, A.I.; Popovskya, G.I. Krugovorot Organicheskogo Veshchestva v Ozere Baikal [Organic Substance Cycle in Lake Baikal]; Nauka Publ.: Novosibirsk, Russia, 1975; 190p. (In Russian)

11. Vadeboncoeur, Y.; McIntyre, P.B.; Vander Zanden, M.J. Borders of Biodiversity: Life at the Edge of the World's Large Lakes. BioScience 2011, 61, 526-537. [CrossRef]

12. Popovskaya, G.I. Ecological monitoring of phytoplankton in Lake Baikal. Aquat. Ecosyst. Health Manag. 2000, 3, 215-225. [CrossRef]

13. Shishlyannikov, S.M.; Klimenkov, I.V.; Bedoshvili, E.D.; Mikhailov, I.S.; Gorshkov, A.G. Effect of mixotrophic growth on the ultrastructure and fatty acid composition of the diatom Synedra acus from Lake Baikal. J. Biol. Res. 2014, 21, 1-8. [CrossRef]

14. Rives, D.B.; Jewson, D.H.; Sturm, M.; Battarbee, R.; Flower, R.G.; Mackay, A.W.; Granin, N.G. Quantitative and qualitative relationships between planktonic diatom communities and diatom assemblages in sedimenting material and surface sediments in Lake Baikal, Siberia. Limnol. Oceanogr. 2003, 48, 1643-1661. [CrossRef] 
15. Behrenfeld, M.J.; O’Malley, R.T.; Siegel, D.A.; McClain, C.R.; Sarmiento, J.L.; Feldman, G.C.; Milligan, A.J.; Falkowski, P.G.; Letelier, R.; Boss, E. Climate-driven trends in contemporary ocean productivity. Nature 2006, 444, 752-755. [CrossRef]

16. Ansari, A.A.; Gill, S.S.; Lanza, G.R.; Rast, W. Eutrophication: Causes, Consequences and Control; Springer: Dordrecht, The Netherlands; Heidelberg, Germany; London, UK; New York, NY, USA, 2011; 394p.

17. Häder, D.P.; Gao, K. Interactions of anthropogenic stress factors on marine phytoplankton. Front. Environ. Sci. 2015, 3, 1-14. [CrossRef]

18. Echeveste, P.; Galbán-Malagón, C.; Dachs, J.; Berrojalbiz, N.; Agustí, S. Toxicity of natural mixtures of organic pollutants in temperate and polar marine phytoplankton. Sci. Total. Environ. 2016, 571, 34-41. [CrossRef]

19. Grachev, M.; Bukin, Y.; Blinov, V.; Khlystov, O.; Firsova, A.; Bashenkhaeva, M.; Kamshilo, O.; Titova, L.; Bairamova, E.; Bedoshvili, Y.; et al. Is a High Abundance of Spring Diatoms in the Photic Zone of Lake Baikal in July 2019 Due to an Upwelling Event? Diversity 2021, 13, 504. [CrossRef]

20. Odum, E.P.; Barrett, G.W. Fundamentals of Ecology, 5th ed.; Cengage Learning: Boston, UK, 2004; 624p.

21. Votintsev, K.K.; Glazunov, I.V. Hydrochemical regime of Lake Baikal near settlement of Listvennichnyi//Transactions of the Limnological Institute. V. III (XXIII). In Hydrochemical Investigations of Lake Baikal; Galazii, G.I., Ed.; AS RAS Publ.: Moscow, Russia, 1963; pp. 3-56. (In Russian)

22. Sokolnikov, V.M. Flows in deep layers and water cycle in Baikal. In Flows and Diffusion of Baikal Water; Galazii, G.I., Ed.; AS RAS Publ.: Moscow, Russia, 1963; pp. 67-74. (In Russian)

23. Afanasyev, A.N.; Verbolov, V.I. Techeniya v Baikale [Flows in Baikal]; Nauka: Novosibirsk, Russia, 1977; 160p. (In Russian)

24. Ladeishchikov, N.P. Izuchenie klimata Baikala [Baikal Climate Investigation]. In the Way for Knowledge of Baikal; Afanasieva, E.L., Beckman, M.Y., Bezrukova, E.V., Verbolov, V.I., Votintcev, K.K., Galazii, G.I., Goldyrev, G.S., Granina, L.Z., Dryukker, V.V., Ladeishokov, N.P., et al., Eds.; Nauka Publ.: Novosibirsk, Russia, 1987; pp. 76-84. (In Russian)

25. Goldman, C.R.; Elser, J.J.; Richards, R.C.; Reuter, J.E.; Priscu, J.C.; Levin, A.L. Thermal stratification, nutrient dynamics and phytoplankton productivity during the onset of spring phytoplankton growth in Lake Baikal, Russia. Hydrobiologia 1996, 331, 9-24. [CrossRef]

26. Genkai-Kato, M.; Sekino, T.; Yoshida, T.; Miyasaka, H.; Khoszher, T.; Belykh, O.A.; Melnik, N.G.; Kawabata, Z.; Higashi, M.; Nakanishi, M. Nutritional diagnosis of phytoplankton in Lake Baikal. Ecol. Res. 2002, 17, 135-142. [CrossRef]

27. Falk-Petersen, S.; Sargent, J.R.; Henderson, J.; Hegseth, E.N.; Hop, H.; Okolodkov, Y.B. Lipids and fatty acids in ice algae and phytoplankton from the Marginal Ice Zone in the Barents Sea. Polar Biol. 1998, 20, 41-47. [CrossRef]

28. Zhila, N.O.; Kalacheva, G.S. Effect of salinity on the biochemical composition of the alga Botryococcus braunii Kütz IPPAS H-252. J. Appl. Phycol. 2011, 23, 47-52. [CrossRef]

29. Wagenen, J.V.; Miller, T.W.; Hobbs, S.; Hook, P.; Crowe, B.; Huesemann, M. Effect of Light and Temperature on fatty acid production in Nannochloropsis Salina. Energies 2012, 5, 731-740. [CrossRef]

30. Costantini, D. Oxidative Stress and Hormesis in Evolutionary Ecology and Physiology; Springer: Heidelberg, Germany; New York, NY, USA; Dordrecht, The Nehterlands; London, UK, 2014; 346p.

31. Nikonova, A.A.; Shishlyannikov, S.M.; Shishlyannikova, T.A.; Avezova, T.N.; Babenko, T.A.; Belykh, O.I.; Glyzina, O.Y.; Obolkin, V.A.; Pavlova, O.N.; Smagunova, A.N.; et al. Determination of Free and Esterified Fatty Acids in Hydrocoles of Different Content of Polyunsaturated Fatty Acids by Gas-Liquid Chromatography. J. Anal. Chem. 2020, 75, 1310-1321. [CrossRef]

32. Abedi, E.; Sahari, A.M. Long-chain polyunsaturated fatty acid sources and evaluation of their nutrition and functional properties. Food Sci. Nutr. 2014, 2, 443-463. [CrossRef] [PubMed]

33. Berg, J.M.; Tymoczko, J.L.; Stryer, L. Biochemistry, 5th ed.; W. H. Freeman and Company: New York, NY, USA, 2002; 1208p.

34. Goncalves, A.M.M.; Marques, J.C.; Goncalves, F. Fatty Acids' Profiles of Aquatic Organisms: Revealing the Impacts of Environental and Anthropogenic Stressors; Intech Open: London, UK, 2017; Chapter 6; pp. 89-117.

35. Arts, M.T.; Ackman, R.G.; Holub, B.J. "Essential fatty acids" in aquatic ecosystems: A crucial link between diet and human health and evolution. Can. J. Fish. Aquat. Sci. 2001, 58, 122-137. [CrossRef]

36. Hampel, M.; Ortiz-Delgado, J.B.; Sarasquete, C.; Blasco, J. Effects of sediment sorbed linear alkylbenzene sulphonate on juveniles of the Senegal sole, Solea senegalensis: Toxicity and histological indicators. Histol. Histopathol. 2008, 23, 87-100. [PubMed]

37. Katagi, T. Surfactant Effects on Environmental Behavior of Pesticides. Rev. Environ. Contam. Toxicol. 2008, 194, 71-177.

38. Zelzer, S.; Oberreither, R.; Bernecker, C.; Stelzer, I.; Truschnig-Wilders, M.; Fauler, G. Measurement of total and free malondialdehyde by gas-chromatography mass spectrometry-comparison with high-performance liquid chromatography methology. Free. Radic. Res. 2013, 47, 651-656. [CrossRef]

39. Janero, D.R. Malondialdehyde and thiobarbituric acidreactivity as diagnostic indices of lipid peroxidation and peroxidative tissue injury. Free Radic. Biol. Med. 1990, 9, 515-540. [CrossRef]

40. Lopez, C.A.; Mendez, J.C. Anticancer drugs acting via radical species, photosensitizers and photodynamic therapy of cancer. Chapter 4. In Medicinal Chemistry of Anticancer Drugs; Carmen, A., Carlos Menéndez, J., Eds.; Elsevier B.V.: Madrid, Spain, 2008; pp. 93-138.

41. Marnett, L.J. Lipid peroxidation-DNA damage by malondialdehyde. Mutat. Res. Fundam. Mol. Mech. Mutagenesis 1999, 424, 83-95. [CrossRef]

42. Zhou, J.; Wu, Z.; Yu, D.; Pang, Y.; Cai, H.; Liu, Y. Toxicity of linear alkylbenzene sulfonate to aquatic plant Potamogeton perfoliatus L. Environ. Sci. Pollut. Res. 2018, 25, 32303-32311. [CrossRef] [PubMed] 
43. Bondarenko, N.A.; Logacheva, N.F. Structural Changes in Phytoplankton of the Littoral Zone of Lake Baikal. Hydrobiol. J. 2017, 53, 16-24. [CrossRef]

44. Popovskaya, G.I.; Usoltseva, M.V.; Domysheva, V.M.; Sakirko, M.V.; Blinov, V.V.; Khodzher, T.V. The spring phytoplankton in the pelagic zone of Lake Baikal during 2007-2011. Geogr. Nat. Resoures 2015, 36, 253-262. [CrossRef]

45. Timoshkin, O.A.; Samsonov, D.P.; Yamamuro, M.; Moore, M.V.; Belykh, O.I.; Malnik, V.; Sakirko, M.; Shirokaya, A.; Bondarenko, N.; Domysheva, V.; et al. Rapid ecological change in the coastal zone of Lake Baikal (East Siberia): Is the site of the world's greatest freshwater biodiversity in danger? J. Great Lakes Res. 2006, 42, 487-497. [CrossRef]

46. Khanaev, I.V.; Kravtsova, L.S.; Maikova, O.O.; Bukshuk, N.A.; Sakirko, M.V.; Kulakova, N.V.; Butina, T.V.; Nebesnykh, I.A.; Belikov, D.I. Current state of the sponge fauna (Porifera: Lubomirskiidae) of Lake Baikal: Sponge disease and the problem of conversation of diversity. J. Great Lakes Res. 2018, 44, 77-85. [CrossRef]

47. Maikova, O.O.; Kravtsova, L.S.; Khanaev, I.V. Baikal endemic sponges in the system of ecological monitoring. Limnol. Freshw. Biol. 2020, 1, 364-367. [CrossRef]

48. Moselhy, H.F.; Reid, R.G.; Yousef, S.; Boyle, S.P. A specific, accurate, and sensitive measure of total plasma malondialdehyde by HPLC. J. Lipid Res. 2013, 54, 852-858. [CrossRef]

49. Al-Rashed, S.A.; Ibrahim, M.M.; El-Gaaly, G.A.; Al-Shehri, S.; Mostafa, A. Evaluation of radical scavenging system in two microalgae in response to interactive stresses of UV-B radiation and nitrogen starvation. Saudi J. Biol. Sci. 2016, 23, 706-712. [CrossRef]

50. Rakita, S.M.; Colovie, D.S.; Levart, A.R.; Banjac, V.V.; Colovie, R.R.; Dragojlović, D.M.; Đuragić Olivera, M. A rapid spectrophotometric method for determination of thiobarbituric acid reactive substances in rainbow trout feed. Food Feed Res. 2020, 47, 43-53. [CrossRef]

51. Smagunova, A.N. Metody Matematicheskoi Statistiki v Analiticheskoi Khimii [Methods of Mathematical Statistics in Analytical Chemistry]; Gosudarstvennyi Universitet: Irkutsk, Russia, 2008; 340p. (In Russian)

52. Mardia, K.V.; Kent, J.T.; Bibby, J.M. Multivariate Analysis; Academic Press Limited Publ.: London, UK, 1979; 100p.

53. Yule, G.U.; Kendall, M.G. An Introduction to the Theory of Statistics, 14th ed.; Griffin \& Company Publ.: Glasgow, UK, 1950; 701p.

54. Liu, N.; Wu, Z. Toxic effects of linear alkylbenzene sulfonate on Chara vulgaris L. Environ. Sci. Pollut. Res. 2018, $25,4934-4941$. [CrossRef] [PubMed]

55. Srivastava, S.; Tripathi, G.; Mishra, S.; Gupta, G. Copper-induced oxidative stress and responses of antioxidants and phytochelatins in Hydrilla verticillata (L.f.). Royle Aquatic Toxicol. 2006, 8, 405-415. [CrossRef] [PubMed]

56. Vega-López, A.; Ayala-López, G.; Posadas-Espadas, B.P.; Olivares-Rubio, H.F.; Dzul-Caamal, R. Relations of oxidative stress in freshwater phytoplankton with heavy metals and polycyclic aromatic hydrocarbon. Comp. Biochem. Physiol. Part A Mol. Integr. Physiol. 2013, 165, 498-507. [CrossRef]

57. Guoa, J.; Penga, J.; Leia, Y.; Kanervab, M.; Lia, Q.; Song, J.; Guo, J.; Sun, H. Comparison of oxidative stress induced by clarithromycin in two freshwater microalgae Raphidocelis subcapitata and Chlorella vulgaris. Aquat. Toxicol. 2020, $219,105376$. [CrossRef] [PubMed]

58. Nikonova, A.A. Organic synthetic anionic surfactants as persistent organic pollutants of water ecosystems. Limnol. Freshw. Biol. 2020, 4, 620-621. [CrossRef]

59. Lewis, A.M. Chronic and sublethal toxicities of surfactants to aquatic animals: A review and risk assessment. Water Res. 1991, 25, 101-113. [CrossRef]

60. Jorgensen, E.; Christoffersen, K. Short-term effects of linear alkylbenzene sulfonate on freshwater Plankton studied under field conditions. Environ. Toxicol. Chem. 2000, 19, 904-911. [CrossRef]

61. Stamatelatou, K.; Pakou, C.; Lyberatos, G. 6.37.4.1. Linear alkylbenzene sulfonates (LAS). Occurrence, toxicity, and biodegradation of selected emerging priority pollutants in municipal sewage sludge. In Comprehensive Biotechnology, 2nd ed.; Moo-Young, M., Ed.; Pergamon: Oxford, UK, 2011; Volume 6, pp. 473-484.

62. Vorobyeva, S.S. Phytoplankton assemblages of the Southern Baikal in 1990-1995 and 2016-2018. Limnol. Freshw. Biol. 2018, 2, 141-143. [CrossRef]

63. Bondarenko, N.A.; Vorobyova, S.S.; Zhuchenko, N.A.; Golobokova, L.P. Current state of phytoplankton in the littoral area of Lake Baikal, spring 2017. J. Great Lakes Res. 2020, 46, 17-28. [CrossRef]

64. Vologina, E.G.; Sturm, M.; Vorobyeva, S.S. Present Sedimentation in Lake Baikal. Experimental Results with Sedimentary Traps. Dvenadtsatoe Uralskoe Litilogicheskoe Soveshanie [12th Ural Litologic Workshop]; IGGUrO RAN Publ.: Ekaterinburg, Russia, 2018; pp. 62-63.

65. Tomberg, I.V.; Sakirko, M.V.; Domysheva, V.M.; Sez'ko, N.P.; Lopatina, I.N.; Bashenkhaeva, N.V.; Philevich, E.A.; Kulikova, N.N.; Popova, O.V.; Malnik, V.V.; et al. First Data about Chemical Composition of Interstitial Water of Lake Baikal Splash Zone; Series "Biology. Ecology"; Izvestiya Irkutskogo Gosudarstvennogo Universiteta [Bull. of Irkutsk State University]: Irkutsk, Russia, 2012; Volume 5, pp. 64-74. (In Russian)

66. Rusinek, O.T.; Takhteev, V.V.; Gladkochub, D.P.; Khodzher, T.V.; Budnev, N.M.; Bezrukova, E.V.; Galkin, V.V.; Galkina, V.I.; Granina, L.Z.; Goryunova, O.I.; et al. Baikalogy: In 2 books. Book 1; Nauka Publ.: Novosibirsk, Russia, 2012; 468p. 
67. Krotova, V.A. Geostrophic Baikal Water Circulation at the Straight Stratification Period. Trudy Limnologicheskogo Institute SO AN SSSR [Transactions of Limnological Institute SB RAS, USSR]; Nauka Publ.: Leningrad, Russia, 1970; pp. 11-45. (In Russian)

68. Gagarinova, O.V.; Belozertseva, I.A.; Vorobyeva, I.B.; Vlasova, N.V.; Emelyanova, N.V.; Sorokovoi, A.A. Anthropogenic transformations in the mouth area of tributaries as factors of negative impact on Lake Baikal. Water 2021, 13, 1295. [CrossRef] 